\title{
Isotopic evidence of nitrate degradation by a zero-valent iron permeable reactive barrier: Batch experiments and a field scale study
}

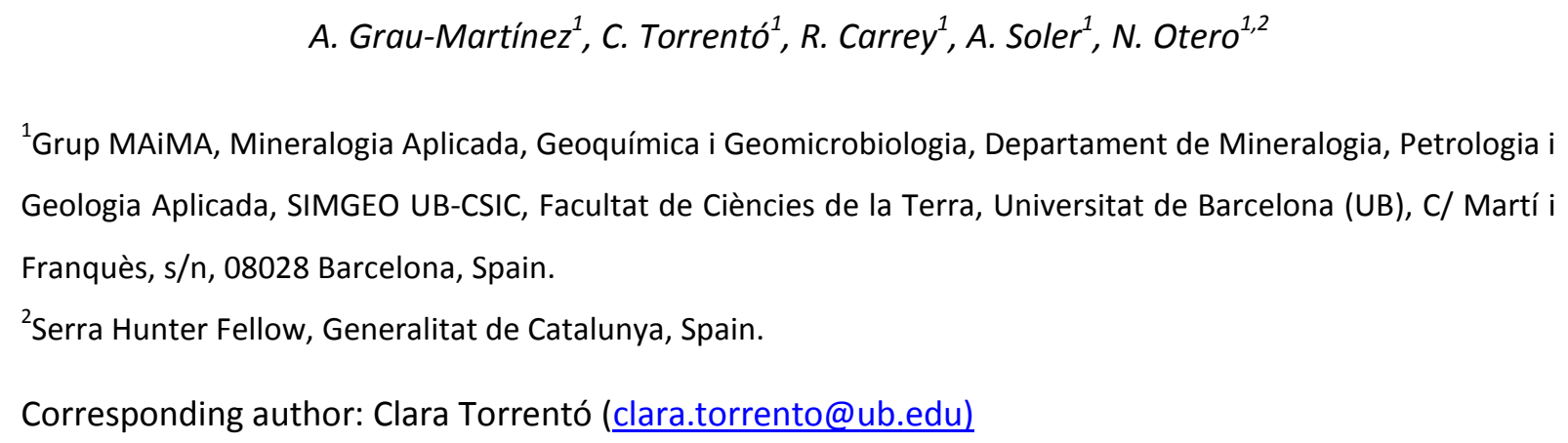

\section{Abstract}

Permeable reactive barriers (PRBs) filled with zero-valent iron (ZVI) are a well-known remediation approach to treat groundwater plumes of chlorinated volatile organic compounds as well as other contaminants. In field implementations of ZVI-PRBs designed to treat these contaminants, nitrate consumption has been reported and has been attributed to direct abiotic nitrate reduction by ZVI or to denitrification by autochthonous microorganisms using the dissolved hydrogen produced from ZVI corrosion. Isotope tools have proven to be useful for monitoring the performance of nitrate remediation actions. In this study, we evaluate the use of isotope tools to assess the effect of ZVIPRBs on the nitrate fate for the further optimization of full-scale applications. Laboratory batch experiments were performed using granular cast ZVI and synthetic nitrate solutions at $\mathrm{pH} 4-5.5$ or nitrate-containing groundwater $(\mathrm{pH}=7.0)$ from a field site where a ZVI-PRB was installed. The experimental results revealed nitrate attenuation and ammonium production for both types of experiments. In the field site, the chemical and isotopic data demonstrated the occurrence of ZVIinduced abiotic nitrate reduction and denitrification in wells located close to the ZVI-PRB. The isotopic characterization of the laboratory experiments allowed us to monitor the efficiency of the ZVI-PRB at removing nitrate. The results show the limited effect of the barrier (nitrate reduction of 
less than $15-20 \%)$, probably related to its non-optimal design. Isotope tools were therefore proven to

27 be useful tools for determining the efficacy of nitrate removal by ZVI-PRBs at the field scale.

28 Keywords: groundwater remediation, passive treatment system, abiotic nitrate reduction, denitrification, multi-isotope analysis.

30

\section{Introduction}

Nitrate $\left(\mathrm{NO}_{3}{ }^{-}\right)$contamination in groundwater is a common and increasing global problem that affects drinking water supplies around the world. Biological denitrification is the major nitrate removal mechanism under natural conditions. However, in many contaminated aquifers, the activity of nitrate-reducing bacteria is limited by the availability of electron donors (Rivett et al., 2008). Therefore, over the last couple of decades, various remediation techniques have been explored for groundwater clean-up (Khan et al., 2004). One of the innovative technologies used for in situ remediation of contaminated groundwater is the use of permeable reactive barriers (PRBs) (USEPA, 2002; Tratnyek et al., 2003). This in situ remediation technique involves the interception of groundwater flow to remove contaminants by physical, chemical or biological processes. Several constructed PRBs filled with zero-valent iron $(\mathrm{ZVI})$ have been used to treat groundwater contaminated with chlorinated volatile organic compounds (O'Hannesin and Gillham, 1998; Phillips et al., 2010; Wilkin et al., 2014; Audí-Miró et al., 2015), chromium (VI) (Flury et al., 2009; Wilkin et al., 2014), sulfates (Da-Silva et al., 2007), pesticides (Yang et al., 2010), explosives (Da-Silva et al., 2007; Johnson and Tratnyek, 2008) or radionuclides, such as uranium (Gu et al., 2002a; Morrison et al., 2002).

The success of these barriers has stimulated significant interest in the application of ZVI to other contaminants, such as nitrate. Gu et al. (2002a) observed decreases in nitrate concentrations in downgradient (and some upgradient) monitoring wells of a ZVI-PRB installed to remove the radionuclides uranium and technetium. The decrease in the nitrate content was attributed to direct abiotic nitrate reduction by ZVI or to denitrification by microorganisms that use the dissolved hydrogen produced from ZVI corrosion. Morrison et al. (2002) also observed decreases in nitrate 
contents in monitoring wells located in and around a ZVI-PRB installed in a former uranium milling site for the removal of uranium and vanadium. Nitrate removal has also been reported in a ZVI pilotscale funnel-and-gate system designed to treat groundwater contaminated with trichloroethylene (Yabusaki et al., 2001). Finally, Hosseini et al. (2018) demonstrated the efficiency in nitrate removal from groundwater of non-pumping reactive wells (NPRWs) filled with a mixture of nano/micro ZVI in bench-scale laboratory tests.

At the laboratory scale, numerous studies have demonstrated the effectiveness of ZVI for the abiotic reduction of nitrate (Huang et al., 1998; Westerhoff and James, 2003; Huang and Zhang, 2004; Shin and Cha, 2008, Liu et al., 2013; Zhang et al., 2017). The following reaction pathway (Eq. 1) has been proposed to be the dominant one during abiotic nitrate reduction by ZVI (Yang and Lee, 2005; Rodríguez-Maroto et al., 2009):

$$
4 F e
$$

Ammonium is the main product in nitrate reduction by ZVI (Huang et al., 1998; Li et al., 2010; Suzuki et al., 2012), although other products, such as nitrite and nitrogen gas, have also been reported (Choe et al., 2000; Shin and Cha, 2008). The main limitation in the application of ZVI-PRB to reduce nitrate is therefore the generation of ammonium ions that are potentially toxic to aquatic organisms at high concentrations (Shin and Chan, 2008; Hwang et al., 2011; Suzuki et al., 2012). Furthermore, since nitrate is corrosive to $\mathrm{ZVI}$, clogging processes may affect the performance of hydraulic PRBs (Gu et al., 2002a; Ritter et al., 2002), especially at high nitrate concentrations (Kamolpornwijit et al., 2003; Liang et al., 2005).

The combined use of $\mathrm{ZVI}$ and a carbon substrate for in situ biochemical denitrification has been considered in recent years and has been shown to be effective at the laboratory scale in improving denitrification rates (Della Rocca et al., 2006; Della Rocca et al., 2007). Huang et al. (2015) and Hosseini and Tosco (2015) demonstrated the efficacy of nitrate removal from contaminated groundwater by a combination of ZVI and carbon substrates (pine bark, beech sawdust and maize 
cobs) in laboratory tests. Liu et al. (2013) demonstrated that the main role of ZVI in two-layer permeable reactive barriers consisting of $\mathrm{ZVI}$ and activated carbon immobilizing denitrifying microbial consortia was as an oxygen capturing reagent and not for direct nitrate reduction.

When iron metal is immersed in water under anaerobic conditions, its corrosion produces cathodic hydrogen following Eq. 2 (Reardon, 1995). This cathodic hydrogen can be used as an electron donor by autotrophic denitrifiers for nitrate reduction (Till et al., 1998) (Eq. 3).

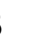
(1)

The use of this cathodic hydrogen as an energy source to support bacterial growth has been demonstrated for several types of anaerobic pure cultures, including autotrophic denitrifiers (Till et al., 1998) and methanogenic, homoaceotogenic, and sulfate-reducing bacteria (Daniels et al., 1987; Rajagopal and LeGall, 1989). An indigenous hydrogenotrophic consortium is thus likely to eventually develop around a hydrogen-producing ZVI-PRB. Gu et al. (2002b) found that the depletion of dissolved oxygen and the production of cathodic hydrogen by ZVI corrosion in a ZVI-PRB designed for the sequestration or removal of uranium provided a reducing environment favorable to many hydrogen-consuming anaerobic microorganisms, such as sulfate and metal-reducing bacteria, methanogens, and denitrifying bacteria. Da Silva et al. (2007) also identified several bacteria that could utilize hydrogen produced during anaerobic ZVI corrosion in groundwater samples from within and around a ZVI-PRB installed for the remediation of a site contaminated with explosives. Denitrifying bacteria may therefore greatly increase the rate and extent of nitrate reduction in the reducing zone of a ZVI-PRB. The combination of ZVI-driven nitrate reduction with denitrification by autohydrogenotrophic denitrifying bacteria has been proved at the laboratory scale, resulting in an increase in the nitrate removal rate and a decrease in ammonium release (Dejournett and Alvarez, 2000; Shin and Cha, 2008; An et al., 2009). 
Induced nitrate attenuation at the field scale may be masked by several processes, such as

102 dispersion, diffusion or dilution (mixing), which can change the nitrate concentration in groundwater.

103 The isotopic fractionation of $N\left(\varepsilon^{15} N\right)$ and $O\left(\varepsilon^{18} O\right)$ of dissolved nitrate calculated following a Rayleigh

104 distillation process in lab-scale experiments of denitrification with ZVI may be used in future studies

105 to assess the behavior of the system in the field and optimize full-scale applications. To the authors'

106 knowledge, the oxygen and nitrogen isotopic fractionations associated with nitrate reduction by ZVI

107 have not yet been reported in the literature. The potential use of the in situ measurement of the

108 isotopic composition of nitrate to assess the effectiveness of ZVI-PRBs at removing nitrate has yet to

109 be evaluated.

110 The main objective of this study is therefore to determine the nitrogen and oxygen isotope

111 fractionations $\left(\varepsilon^{15} \mathrm{~N}\right.$ and $\left.\varepsilon^{18} \mathrm{O}\right)$ associated with the ZVI-driven nitrate reduction reaction to investigate

112 the potential of isotope analyses to assess the fate of nitrate in a PRB-ZVI installed in a site

113 contaminated with volatile organic compounds where high nitrate concentrations in groundwater

114 are detected.

\section{2. Study area}

116 The study site is located in the industrial area of Granollers, $20 \mathrm{~km}$ NW of Barcelona, Catalonia. An

117 automotive industry that used tetrachloroethene and trichloroethene as degreasers operated in the

118 area from 1965 to 1989 . Groundwater contamination by chlorinated solvents resulted from the

119 discharge of industrial waters into a seepage pit located to the south of the plant (close to MW17 well, Fig. 1). The lithology of the site is mainly composed of an alternation of sand and silt Miocene sediments in a clay matrix that extends from $4 \mathrm{~m}$ to a minimum of $14 \mathrm{~m}$ in depth (Audí-Miró et al., 2015). Above these materials, there are $4 \mathrm{~m}$ of quaternary glacis formed by the Miocene materials that are mainly composed of poorly structured clays and silts. The water table of the aquifer is located at an average depth of $5.4 \pm 2.1 \mathrm{~m}$. The deepest water table (approximately $8 \mathrm{~m}$ ) was measured at the base and at the top of the studied valley area (length of the studied area is $900 \mathrm{~m}$ ). 
(approximately $3 \mathrm{~m}$ in depth) (Fig. 1). The average water table variation due to seasonal changes was

$128-0.5 \pm 0.9 \mathrm{~m}$. The groundwater flow direction was NE to W-SW, and the flow velocity was estimated 129 at approximately $0.16 \mathrm{~m} \mathrm{day}^{-1}$ at the shallow quaternary clay depth and $0.84 \mathrm{~m} \mathrm{day}^{-1}$ at the sandier 130 Miocene depth (Audí-Miró et al., 2015). The site is crossed by the Can Ninou Creek along which a 131 piezometer network was installed (Fig. 1).

132

133

134 In 2009, contaminated soil from the source area was removed, and in 2010, a ZVI-PRB was installed (Audí-Miró et al., 2015). The ZVI-PRB was built approximately $320 \mathrm{~m}$ downgradient of the contaminated source, transverse to the creek, from NW to SE (Fig. 1). The top of the PRB was placed 4-5 $\mathrm{m}$ below the ground surface, and its size is $20 \mathrm{~m}$ long, $5 \mathrm{~m}$ high and $60 \mathrm{~cm}$ thick, with a $3 \%(\mathrm{v} / \mathrm{v})$ granular cast ZVI inside a sand matrix.

The piezometer network consists of 12 conventional wells and 5 multilevel wells. The conventional wells were installed between 2005 and 2010 along the east bank of the creek (expected direction of groundwater flow) from the source area to $900 \mathrm{~m}$ downgradient of the creek (Fig. 1). The wells consists of $50 \mathrm{~mm}$ inner diameter PVC pipes screened from 3 to $12 \mathrm{~m}$ depth, except MW17 and OMW5 wells, screened from 5 to $10 \mathrm{~m}$ and from 7 to $11 \mathrm{~m}$, respectively. In March 2012, five additional wells were installed surrounding the barrier, two immediately upgradient of the PRB and three immediately downgradient. These five wells have a multilevel sampling system installed consisting of a bundle of small-diameter $(5 \mathrm{~mm}$ outer diameter) PTFE tubes surrounding the monitoring well casing and positioned at different depths, providing the possibility to obtain several depth discrete groundwater samples from the same borehole (from 2 to $13.5 \mathrm{~m}$ depth, with a $0.5 \mathrm{~m}$ interval).

\section{Materials and Methods}

\subsection{Laboratory-scale experiments}

Batch experiments were carried out in triplicate using $40 \mathrm{~mL}$ glass bottles. Each bottle contained 6.75 g of cast iron (92\% purity, Gotthart Maier Metall pulver $\mathrm{GmbH}$, Rheinfelden, Germany) and $35 \mathrm{~mL}$ of 
a nitrate-containing aqueous solution. Prior to the experiment, the $\mathrm{ZVI}$ was acid-cleaned with $1 \mathrm{~N}$

153 degassed $\mathrm{HCl}$ for $1 \mathrm{~h}$ and then rinsed five times with degassed deionized water (Milli-Q Plus UV,

154 Millipore $^{\mathrm{TM}}$, Billerica, Massachusetts, USA), dried and stored inside a sterilized and anaerobic

155 chamber with a $\mathrm{N}_{2}$ atmosphere at $+28 \pm 2{ }^{\circ} \mathrm{C}$ (Matheson and Tratnyek, 1994; Dayan et al., 1999;

156 Slater et al., 2002). In the chamber, UV light was used to sterilize the iron. The ZVI was weighed

157 before and after the treatment to verify that it was dry. The specific surface area of the cast iron

158 determined by $\mathrm{N}_{2}$ gas adsorption (BET method) (Brunauer et al., 1938) was $1.624 \pm 0.007 \mathrm{~m}^{2} \mathrm{~g}^{-1}$. The

159 size of the iron particles ranged between 0.4 to $2.0 \mathrm{~mm}$, with an average diameter of $1.2 \mathrm{~mm}$

160 (Torrentó et al., 2017).

161 Three different solutions were used: Milli-Q water ( $\mathrm{pH}=5.5$ ) (MQ experiments), a $\mathrm{pH} 4 \mathrm{HCl} 0.1 \mathrm{M}$ 162 solution ( $\mathrm{pH} 4$ experiments) and groundwater $(\mathrm{pH}=7.0)$ from a piezometer (PZ10) located 163 immediately upgradient of the ZVI-PRB installed in the study site (PRB experiments). All of the 164 synthetic solutions contained $1.93 \mathrm{mM}$ of nitrate, whereas the content of nitrate in the groundwater 165 sample was $2.93 \mathrm{mM}$.

166 The experiments were set up inside the glove box with an argon atmosphere to avoid the presence 167 of $\mathrm{O}_{2}$. After preparation, the bottles were immediately covered with aluminum foil to avoid oxidation 168 due to light, and they were removed from the glove box and rotated on a horizontal roller table 169 (Wheaton, Millville, New Jersey, USA) at $60 \mathrm{rpm}$ about their longitudinal axes. Experimental runs lasted for 8 days, and aqueous samples were taken daily using sterile syringes purged with $\mathrm{N}_{2}$. All of the samples were filtered through a $0.2 \mu \mathrm{m}$ Millipore ${ }^{\circledR}$ filter and preserved at $4{ }^{\circ} \mathrm{C}$ in darkness prior to further analysis. The concentrations of nitrogen species and the $\delta^{15} \mathrm{~N}$ and $\delta^{18} \mathrm{O}$ of dissolved nitrate were measured in selected samples.

\section{$174 \quad 3.2$ Sampling surveys}

175 To assess the effect of the ZVI-PRB on the nitrate fate, three sampling campaigns were performed in 176 June 2012, October 2012 and March 2013. Both the conventional and multilevel wells were sampled

177 (Fig. 1). The conventional wells were sampled using a portable pump, whereas for the multilevel 
wells, disposable $60 \mathrm{~mL}$ polypropylene sterile syringes were used to raise the water from each smalldiameter PTFE tube. In order to obtain depth discrete samples, the water volume sampled from each

180 tube was minimized as much as possible to prevent interference with the adjacent tubes. For each sampling campaign, selected depths were sampled. For both conventional and multilevel wells, the wells were purged before sampling.

The groundwater piezometric level was measured and the physicochemical parameters $(\mathrm{pH}$, temperature, dissolved oxygen and conductivity) were measured on site using a flow-through cell (Eijkelkamp, Netherlands) connected in line with the sampling tubes to avoid contact with the atmosphere. A Multi3410 multi-parameter meter (WTW, Weilheim, Germany) was used. Samples were collected and preserved in plastic bottles that were filled completely to avoid the oxidation of species from contact with the atmosphere. Samples were preserved at $4{ }^{\circ} \mathrm{C}$ and passed through a 0.2 $\mu \mathrm{m}$ filter in darkness prior to further analysis. In most of the collected samples, the nitrate, nitrite

$190\left(\mathrm{NO}_{2}{ }^{-}\right)$, ammonium $\left(\mathrm{NH}_{4}{ }^{+}\right)$and cation concentrations were measured. The $\delta^{15} \mathrm{~N}$ and $\delta^{18} \mathrm{O}$ of dissolved 191 nitrate were measured in selected samples collected in March 2013. The $\delta^{2} \mathrm{H}_{\mathrm{H} 2 \mathrm{O}}$ and $\delta^{18} \mathrm{O}_{\mathrm{H} 2 \mathrm{O}}$ of water 192 were analyzed in a subset of samples.

\subsection{Analytical methods}

194 Nitrate and nitrite concentrations were determined by high performance liquid chromatography 195 (HPLC) with a WATERS 515 HPLC pump, IC-PAC anion columns and a WATERS 432 detector. 196 Ammonium was analyzed using ionic chromatography (DIONEX ICS5000). For the analysis of major cations, samples were acidified with $1 \%$ nitric acid. The cation concentrations were determined by inductively coupled plasma-optical emission spectrometry (ICP-OES, Perkin-Elmer Optima 3200 RL). Chemical analyses were conducted at the "Centres Científics i Tecnològics" of the Universitat de Barcelona (CCiT-UB) and "Institut Català de Recerca de l'Aigua (ICRA)".

201 The $\delta^{15} \mathrm{~N}$ and $\delta^{18} \mathrm{O}$ of dissolved nitrate were determined using a modified cadmium reduction 202 method (Mcllvin and Altabet, 2005; Ryabenko et al., 2009). Briefly, nitrate was converted to nitrite 203 through spongy cadmium reduction and then to nitrous oxide using sodium azide in an acetic acid 
204 buffer. Simultaneous $\delta^{15} \mathrm{~N}$ and $\delta^{18} \mathrm{O}$ analyses of the produced $\mathrm{N}_{2} \mathrm{O}$ were carried out using a Pre-Con 205 (Thermo Scientific) coupled to a Finnigan MAT-253 Isotope Ratio Mass Spectrometer (IRMS, Thermo 206 Scientific). $\delta^{2} \mathrm{H}_{\mathrm{H} 2 \mathrm{O}}$ was measured by pyrolysis using a Thermo-Quest high-temperature conversion 207 analyzer (TC/EA) unit with a Finnigan MAT Delta C IRMS. $\delta^{18} \mathrm{O}_{\mathrm{H} 2 \mathrm{O}}$ was measured using the $\mathrm{CO}_{2}$ 208 equilibrium technique following the standard method (Epstein and Mayeda, 1953) using a GasBench coupled to the MAT-253 IRMS. The notation was expressed in terms of $\delta$ relative to international standards (V-SMOW for $\delta^{2} \mathrm{H}_{\mathrm{H} 2 \mathrm{O}}$ and $\delta^{18} \mathrm{O}_{\mathrm{H} 2 \mathrm{O}}$ and V-AIR for $\delta^{15} \mathrm{~N}$ ). According to Coplen (2011), several

211 international and laboratory standards were interspersed among the sequences for the normalization of analyses. The analytical reproducibility by repeated analysis of both international and internal reference samples of known isotopic composition was $\pm 1 \%$ o for $\delta^{15} \mathrm{~N}_{\mathrm{NO} 3}, \pm 1.5 \%$ ofor $\delta^{18} \mathrm{O}_{\mathrm{NO} 3}, \pm 1 \%$ of $\delta^{2} \mathrm{H}_{\mathrm{H} 2 \mathrm{O}}$, and $\pm 0.3 \%$ for $\delta^{18} \mathrm{O}_{\mathrm{H} 2 \mathrm{O}}$. Samples for isotopic analyses were prepared at the MAiMA laboratory and determined at CCIT-UB.

\subsection{Isotope fractionation calculation}

217 Isotopic fractionation during nitrate transformation is commonly calculated in laboratory 218 experiments in which the conditions are well constrained, no other sinks affect the nitrate pool and 219 the changes in the concentration and the isotopic composition of nitrate can be considered to be 220 exclusively determined by the nitrate transformation process. The process is modeled following a 221 Rayleigh distillation. Using the Rayleigh equation (Eq. 4), the isotopic fractionation factor $\alpha$ can be obtained (Aravena and Robertson, 1998; Mariotti et al., 1988):

where $C_{0}$ and $C_{t}$ are the nitrate concentrations at the beginning and at a given time $(t)$, respectively (mmol L ${ }^{-1}$ ), and $\mathrm{R}_{0}$ and $\mathrm{R}_{\mathrm{t}}$ denote the ratios of heavy versus light isotopes at the beginning and at time t, respectively, which are calculated according to Eq. 5 . 
where $\delta$ is the isotopic composition of ${ }^{15} \mathrm{~N}$ and ${ }^{18} \mathrm{O}(\%)$. The term $(\alpha-1)$ is calculated from the slope 229 of the regression analysis in double-logarithmic plots, $\left[\ln \left(R_{t} / R_{0}\right)\right]$ over $\left[\ln \left(C_{t} / C_{0}\right)\right]$, according to Eq. 4 230 and is converted to isotopic fractionation $\left(\varepsilon^{15} \mathrm{~N}\right.$ and $\left.\varepsilon^{18} \mathrm{O}\right)$ following Eq. 6.

With the $\varepsilon$ values obtained in the laboratory experiments, the percentage of denitrification at the field scale can be calculated according to Eq. 7 using either $\varepsilon N$ or $\varepsilon \mathrm{O}$, or both.

The isotope signature of the original nitrate $\left(\delta_{\text {initial }}\right)$ is usually assumed to correspond to that of the determined nitrate source or to the lowest value found in the field site.

\section{Results and discussion}

\subsection{Batch experiments: chemical data}

Complete removal of nitrate was observed within 7 days in all batch experiments (Supplementary Material, Table S1). In all experiments, ammonium was produced (maximum values of $2.47 \mathrm{mM}$ for $\mathrm{PRB}, 1.47 \mathrm{mM}$ for $\mathrm{MQ}$ and $1.40 \mathrm{mM}$ for $\mathrm{pH} 4$ ), whereas no significant nitrite contents (maximum values for all experiments ranged from $0.01 \mathrm{mM}$ to $0.03 \mathrm{mM}$, achieved during the first 2-3 days) were detected (Table S1). The nitrogen mass balance in the experiments shows that ammonium and nitrite

244 account for approximately $50-100 \%$ of the nitrate removal in the PRB and $45-75 \%$ in the $\mathrm{MQ}$ and $\mathrm{pH} 4$ 245 experiments (Table S1). According to Chen et al. (2005), sorption of ammonium onto mineral oxides 246 produced by ZVI corrosion (Westerhoff and James, 2003) was ruled out. Thus, gaseous N species 247 should account for closing the nitrogen mass balance. Production of $\mathrm{N}_{2}(\mathrm{~g})$ has been proposed to be a 248 by-product of ZVI-driven nitrate reduction by other authors (Yang and Lee, 2005) in similar experiments. Furthermore, abiotic homogeneous or heterogeneous reduction of nitrite coupled to 
250 the oxidation of the Fe(II) released from the ZVI may also occur, which is also a source of $\mathrm{N}_{2} \mathrm{O}$ 251 (Buchwald et al., 2016).

252 Previous studies (Cheng et al., 1997; Choe et al., 2000; Su and Puls, 2004) have suggested that ZVI253 driven nitrate reduction is first order with respect both nitrate concentration and ZVI concentration. 254 Excluding the effect of ZVI concentration, the reaction was thus assumed to be of pseudo first order 255 with respect to nitrate concentration. Data for nitrate concentration versus time were fit to a pseudo-first-order rate model:

where $C$ is the nitrate concentration, $t$ is time and $k^{\prime}$ is the pseudo-first-order rate constant. The $\mathrm{k}^{\prime}$ was obtained using the integrated form of this equation, from the slope of the regression lines of the In $\mathrm{C} / \mathrm{C}_{0}$ vs. time graph (Fig. 2), where $\mathrm{C}_{0}$ is the initial nitrate concentration. Uncertainty was obtained from the $95 \%$ confidence intervals. The nitrate consumption rate in the experiments with groundwater (PRB experiments) was faster $\left(\mathrm{k}^{\prime}=0.86 \pm 0.09 \mathrm{~d}^{-1}\right)$ than that in the experiments with synthetic solutions ( $\mathrm{MQ}$ and $\mathrm{pH} 4$ experiments, $\mathrm{k}^{\prime}=0.46 \pm 0.04 \mathrm{~d}^{-1}$ for both experiments), suggesting additional nitrate degradation by autochthonous bacteria. The higher nitrate removal in biotic batch experiment (PRB) may be attributed to denitrification by autochthonous denitrifiers, which use the hydrogen or Fe(II) generated by ZVI corrosion as electron donors (Till et al., 1998; Shin and Cha, 2008; An et al., 2009; Jamieson et al., 2018; Xu et al., 2018; Zhang et al., 2019).

The surface-area-normalized reaction rate constants $\left(k_{S A}\right)$ were calculated for comparison with other studies following Eq. 9 (Johnson et al., 1996):

271 where $a_{s}$ is the ZVI specific surface area $\left(\mathrm{m}^{2} \mathrm{~g}^{-1}\right)$ and $\rho m$ is the mass concentration of $\mathrm{ZVI}\left(\mathrm{g} \mathrm{L}^{-1}\right)$.

272 The obtained $\mathrm{k}^{\prime}$ values correspond to $\mathrm{k}_{\mathrm{SA}}$ values of $2.8 \pm 0.3 \times 10^{-3} \mathrm{~L} \mathrm{~m}^{-2} \mathrm{~d}^{-1}$ for the PRB experiment and $2731.6 \pm 0.1 \times 10^{-3} \mathrm{~L} \mathrm{~m}^{-2} \mathrm{~d}^{-1}$ for both the $\mathrm{MQ}$ and $\mathrm{pH} 4$ experiments. For the latter experiments, the 274 obtained $\mathrm{k}_{\mathrm{SA}}$ values are within the range reported for chemical nitrate reduction by $\mathrm{ZVI}\left(1.1 \times 10^{-4}\right.$ to 
$2757.2 \mathrm{~L} \mathrm{~m}^{-2} \mathrm{~d}^{-1}$ for $\mathrm{pH}$ between 7 and 9.5 , and $2.4 \times 10^{-3}$ to $12.3 \mathrm{~L} \mathrm{~m}^{-2} \mathrm{~d}^{-1}$ for $\mathrm{pH}$ values of 3-6.5, Alowitz 276 and Scherer, 2002; Su and Puls, 2004; Choe et al., 2004; Ginner et al., 2004; Miehr et al., 2004).

277 Both abiotic batch experiments ( $\mathrm{pH} 4$ and $\mathrm{MQ}$ ) showed the same reaction rate, suggesting that at the 278 tested conditions ( $\mathrm{pH}=4$ for the $\mathrm{pH} 4$ experiment, $\mathrm{pH}=5.5$ for the $\mathrm{MQ}$ experiment, respectively), $\mathrm{ZVI}$ 279 driven nitrate reduction was independent of the $\mathrm{pH}$. Nevertheless, at $\mathrm{pH}$ values relevant to ZVI-PRBs 280 (pH from 6.5 to 9), slower rates have generally been observed at higher $\mathrm{pH}$ values (Hu et al., 2001; 281 Alowitz and Scherer, 2002; Miehr et al., 2004; Westerhoff and James, 2003; Ginner et al., 2004). In the case of the experiment with combined abiotic nitrate reduction and denitrification (PRB experiment, since the ZVI surface area is not reported in most previous studies, a comparison is performed in terms of the pseudo-first-order rate constants. The $k^{\prime}$ value of the PRB experiment $\left(k^{\prime}=0.86 \pm 0.09 \mathrm{~d}^{-1}\right)$ is similar to that reported by Shin and Cha (2008) using a culture obtained from activated sludge and anaerobic digester samples from a wastewater treatment plant $\left(\mathrm{k}^{\prime}=0.97 \mathrm{~d}^{-1}\right)$, even when the latter used nano ZVI. Previous studies using cast (Ginner et al., 2004) and nano (An et al., 2009) ZVI in combination with pure cultures of denitrifying bacteria resulted in faster nitrate removal rates ( $\mathrm{k}^{\prime}$ from 1.5 to $2.4 \mathrm{~d}^{-1}$ ).

\subsection{Batch experiments: isotopic results}

291 All of the experiments showed considerable enrichment in both ${ }^{15} \mathrm{~N}$ and ${ }^{18} \mathrm{O}$ in the remaining nitrate 292 over the course of the experiments (Table S1), confirming nitrate degradation. In the PRB 293 experiment, $\delta^{15} \mathrm{~N}$ increased from $+8.2 \%$ o to $+154.9 \%$, whereas $\delta^{18} \mathrm{O}$ increased from $+5.4 \%$ o to 294 $+83.5 \%$. Similarly, the $\delta^{15} \mathrm{~N}^{-N_{3}}{ }_{3}^{-}$in the $\mathrm{MQ}$ and $\mathrm{pH} 4$ experiments increased from $+15.6 \%$ and $+15.9 \%$ o to $+133.2 \%$ ond $+135.9 \%$, respectively. The $\delta^{18} \mathrm{O}$ values increased from $+26.5 \%$ o and $+29.3 \%$ o to $+78.2 \%$ ond $+79.9 \%$ in the $\mathrm{MQ}$ and $\mathrm{pH} 4$ experiments, respectively. The $\varepsilon^{15} \mathrm{~N}$ and $\varepsilon^{18} \mathrm{O}$ values in the experiments were obtained from the slope of the linear correlation between the natural logarithm of the remaining fraction of the substrate, $\ln \left(C_{\text {residual }} / C_{\text {initial }}\right)$, where $C$ refers to the analyte concentration, and the determined isotope ratios, $\ln \left(R_{\text {residual }} / R_{\text {initial }}\right)$, following Eq. 4 (Fig. 3). 
302 the $\mathrm{MQ}$ experiment and $-36.1 \pm 7.1 \%$ or $\mathrm{pH} 4$ experiment. The oxygen isotopic fractionation $\left(\varepsilon^{18} \mathrm{O}\right)$ 303 was $-16.4 \pm 1.1 \%$ o for the PRB experiment, $-17.2 \pm 4.2 \%$ or for $\mathrm{MQ}$ experiment, and $-16.1 \pm 3.1 \%$ o 304 for the $\mathrm{pH} 4$ experiment (Fig. 3).

305 The isotope fractionation for abiotic nitrate reduction has not been reported to date; the obtained 306 values were thus compared with those reported for biotic denitrification. The $\varepsilon^{15} N$ and $\varepsilon^{18} O$ values obtained in the present study fell within the range of the values reported in the literature for denitrification in laboratory experiments (Grau-Martínez et al., 2017, and references therein). The $\varepsilon^{15} N$ values were similar to the values obtained by Barford et al. (1999) and Toyoda et al. (2005) for heterotrophic denitrification by pure cultures. With regards to $\varepsilon^{18} \mathrm{O}$, the obtained values were similar to those reported by Wunderlich et al. (2012) for heterotrophic denitrification by pure cultures.

312 In all of the experiments, $\delta^{15} \mathrm{~N}$ showed a linear relationship with $\delta^{18} \mathrm{O}$, with slopes between 0.43 and 3130.54 , yielding $\varepsilon^{18} \mathrm{O} / \varepsilon^{15} \mathrm{~N}$ ratios of $0.54 \pm 0.07$ for the PRB experiment and $0.45 \pm 0.02$ and $0.43 \pm 0.03$ 314 for the $\mathrm{MQ}$ and $\mathrm{pH} 4$ experiments, respectively (Fig. 4 and Table 1). A comparison of the obtained 315 slopes for the regression lines $\left(\varepsilon^{18} \mathrm{O} / \varepsilon^{15} \mathrm{~N}\right)$ was performed by analysis of covariance (ANCOVA). 316 Statistical significance was accepted at the $p<0.05$ level. Since they were highly consistent, the data 317 from the $\mathrm{pH} 4$ and $\mathrm{MQ}$ experiments were combined (Table 1). There is a significant statistical 318 difference between the slope obtained for the experiments with purely abiotic solutions $\left(\varepsilon^{18} O / \varepsilon^{15} \mathrm{~N}=\right.$ $0.43 \pm 0.02)$ and that for the PRB experiment $\left(\varepsilon^{18} \mathrm{O} / \varepsilon^{15} \mathrm{~N}=0.54 \pm 0.07\right)$ (ANCOVA, $p=0.0003$ ). This result leads to the potential application of this approach to distinguish ZVI-driven nitrate reduction and additional degradation of nitrate by the action of autochthonous denitrifying bacteria in field sites where ZVI-PRBs are installed.

\subsubsection{Insights from the $\varepsilon^{18} \mathrm{O} / \varepsilon^{15} \mathrm{~N}$ ratio during abiotic ZVI-driven nitrate reduction}

Abiotic nitrate reduction is the only process that acts in the $\mathrm{MQ}$ and $\mathrm{pH} 4$ batches. To the authors' knowledge, no isotopic fractionation ratio $\left(\varepsilon^{18} \mathrm{O} / \varepsilon^{15} \mathrm{~N}\right)$ for abiotic nitrate reduction using ZVI has been published to date. The $\varepsilon^{18} \mathrm{O} / \varepsilon^{15} \mathrm{~N}$ reported for heterogeneous and homogeneous chemical nitrite 
reduction in the presence of dissolved $\mathrm{Fe}^{2+}$ showed higher values $\left(\varepsilon^{18} \mathrm{O} / \varepsilon^{15} \mathrm{~N}\right.$ from 0.7 to 1.7 ,

328 Buchwald et al., 2016; Grabb et al., 2017). Lower ratios can be produced by the incorporation of 329 oxygen isotopes from water into nitrite and the subsequent re-oxidation of nitrite to nitrate 330 (Wunderlich et al., 2013). Consequently, the isotopic equilibrium tends to reduce the $\varepsilon^{18} \mathrm{O}$ values, 331 decreasing the $\varepsilon^{18} \mathrm{O} / \varepsilon^{15} \mathrm{~N}$ ratio to values of 0.5 . In this study, nitrite re-oxidation can be ruled out for 332 all of the experiments since the batch experiments were performed under anaerobic conditions and 333 nitrite accumulation was below $0.02 \mathrm{mM}$. Furthermore, in the $\mathrm{pH} 4$ and $\mathrm{MQ}$ experiments, with no 334 biotic competition, the dissolved $\mathrm{Fe}^{2+}$ released from $\mathrm{ZVI}$ favored fast chemical nitrite reduction over 335 any potential nitrate re-oxidation. In addition, the fast nitrate consumption and the high isotopic 336 composition of $\delta^{18} \mathrm{O}_{\mathrm{NO} 3}$ observed (up to $+83.5 \%$ ) allowed us to consider the equilibrium isotopic 337 fractionation between water and nitrate to be negligible compared with the kinetic isotopic 338 fractionation during nitrate reduction. Lower $\varepsilon^{18} \mathrm{O} / \varepsilon^{15} \mathrm{~N}$ ratios have also been reported to be 339 produced by different enzymes involved in nitrate reduction (Granger et al., 2008). In this sense, the

340 activity of the periplasmic nitrate reductase (Nap) results in a $\varepsilon^{18} \mathrm{O} / \varepsilon^{15} \mathrm{~N}$ value of $\sim 0.6$, whereas the 341 membrane-bound respiratory nitrate reductase (Nar) tends to produce a fractionation ratio of $\sim 1.0$ 342 (Granger et al., 2008). The transformation of nitrate to ammonium by dissimilatory nitrate reduction 343 to ammonium (DNRA) is considered to mostly be catalyzed by this Nap complex (Kraft et al., 2011).

344 Therefore, the results of the $\mathrm{MQ}$ and $\mathrm{pH} 4$ experiments, without enzymatic function, suggest some 345 mechanistic control in the isotope fractionation ratios obtained for purely chemical nitrate reduction 346 by ZVI. On the other hand, although further research is needed, these results suggest that the use of $347 \quad \varepsilon^{18} \mathrm{O} / \varepsilon^{15} \mathrm{~N}$ to distinguish between biotic (DNRA) and abiotic (ZVI-driven) production of ammonium 348 from nitrate reduction is limited.

349 4.2.2 Insights from the $\varepsilon^{18} \mathrm{O} / \varepsilon^{15} \mathrm{~N}$ ratio during combined abiotic ZVI-driven nitrate reduction and 350 denitrification

351 In the PRB experiment, a biotic nitrate-reduction process was assumed to occur in combination with 352 a purely abiotic ZVI-driven nitrate reduction. This biotic nitrate reduction is likely to be autotrophic 
denitrification by autochthonous denitrifying bacteria using the hydrogen or the $\mathrm{Fe}^{2+}$ released from

$354 \mathrm{ZVI}$, although heterotrophic denitrification with the organic carbon present in groundwater or with 355 the biogenic acetate produced by homoacetogens that utilize cathodic hydrogen cannot be ruled out 356 (Zhang et al., 2019). From the kinetic data collected from all of the experiments (Fig. 2), the proportion of the ZVI-driven nitrate reduction (pathway 1 ) in the overall degradation process (pathway $1+$ pathway 2$)$ was calculated as the rate ratio of the two competing pathways $(\mathrm{F}=$ $\left.\mathrm{k}^{\prime}{ }_{1} /\left(\mathrm{k}^{\prime}{ }_{1}+\mathrm{k}_{2}^{\prime}\right)\right)$, showing a $52 \%$ contribution of purely abiotic ZVI-driven nitrate reduction.

360 The isotopic fractionation values $\left(\varepsilon^{15} N\right.$ and $\left.\varepsilon^{18} O\right)$ for the denitrification process in the PRB experiments (pathway 2) were then estimated using a Rayleigh-type equation for multiple competing degradation pathways following first-order kinetics (Van Breukelen, 2007), as follows (Eq. 10):

where $\varepsilon_{1}$ is the isotope fractionation of pathway 1 (ZVI-driven nitrate reduction, i.e., experiments $\mathrm{pH} 4$ and $\mathrm{MQ}$ ), and $\varepsilon_{\mathrm{A}}$ is the isotope fractionation of the overall degradation process (i.e., the PRB experiment). The obtained values of $\varepsilon^{15} N(-15.5 \%)$ and $\varepsilon^{18} \mathrm{O}(-20.5 \%)$ for the denitrification process in the PRB experiments were used to estimate the corresponding $\varepsilon^{18} O / \varepsilon^{15} N$ ratio $\left(\varepsilon^{18} O / \varepsilon^{15} N\right.$ $=0.76)($ Table 1$)$.

During (heterotrophic and autotrophic) denitrification, the $\varepsilon^{18} \mathrm{O} / \varepsilon^{15} \mathrm{~N}$ ratio reported in laboratory 370 studies ranged from 0.3 (Knöller et al., 2011) to 1.3 (Grau-Martínez et al., 2018) in freshwater 371 environments, whereas in marine environments, the fractionation ratio showed values of $\sim 1.0$ 372 (Casciotti et al., 2002; Granger et al., 2004; Sigman et al., 2005). Autotrophic denitrification 373 experiments using pyrite $\left(\mathrm{FeS}_{2}\right)$ as an electron donor have shown a fractionation ratio of 0.87 374 (Torrentó et al., 2010). A $\varepsilon^{18} \mathrm{O} / \varepsilon^{15} \mathrm{~N}$ ratio of 0.9 has been reported for autotrophic denitrification with 375 aqueous $\mathrm{Fe}^{2+}$ in groundwater (Smith et al., 2017). To the authors' knowledge, the isotopic 376 fractionation ratio for hydrogenotrophic denitrification has not been reported and cannot be 377 compared with the obtained results. Factors such as the $\mathrm{pH}$, salinity or carbon sources showed no 
378 effect on the $\varepsilon^{18} \mathrm{O} / \varepsilon^{15} \mathrm{~N}$ ratio (Granger et al., 2008; Wunderlich et al., 2012). Nevertheless, the 379 microbial community composition can impact the ratio at which the nitrogen and oxygen of nitrate 380 are processed during denitrification (Dähnke and Thamdrup, 2016). Overall, despite the fact that the 381 differences between the $\varepsilon^{18} \mathrm{O} / \varepsilon^{15} \mathrm{~N}$ ratios obtained for $\mathrm{PRB}$ and those of the $\mathrm{pH} 4$ and $\mathrm{MQ}$ experiments suggest the occurrence of denitrification in the former, the responsible reaction could not be addressed.

\subsection{Field study}

\subsubsection{Hydrochemical characterization}

386

387

388

389

390

391

392

393

394

395

396

397

398

399

400

401

402

The results of the chemical characterization of the field samples are detailed in the Supplementary Material (Table S2). The pH values analyzed upgradient of the barrier ranged between 6.7 and 9.0, whereas the $\mathrm{pH}$ values of the multilevel (BR1, BR2, BR3, BR4, BR5) and conventional (PZ10 and PZ11) wells located close to the barrier ranged between 4.4 and 7.5, except for higher values that were found in a few points in June 2012. The PZ4 well, located at the west end of the barrier, presented pH values of approximately 7 in June 2012 and approximately 9 in March 2013. Finally, the pH values in conventional wells downgradient of the ZVI-PRB ranged from 5.4 to 8.8 , similar to the values observed upgradient of the PRB. The $\mathrm{pH}$ analyzed downgradient of the barrier therefore does not correspond to the common increase of $\mathrm{pH}$ that usually occurs after the corrosion of iron with water (Eq. 2), probably due to the relatively high pH-buffering capacity of the aquifer.

The chemical data indicated that reducing conditions prevailed in the aquifer: dissolved oxygen (DO) was found in most of the points below $2 \mathrm{mg} \mathrm{L}^{-1}$; dissolved manganese was present at a concentration up to $1.39 \mathrm{mg} \mathrm{L}^{-1}$; and dissolved iron was detected at a concentration up to $2.5 \mathrm{mg} \mathrm{L}^{-1}$. Furthermore, Audí-Miró et al. (2015) demonstrated that these conditions were conducive to the biodegradation of chlorinated ethenes by reductive dechlorination.

To assess the effect of ZVI-PRB on nitrogen compounds, the evolution of the nitrate, nitrite and ammonium concentrations was monitored along the flow path, upgradient and downgradient of the 
404 throughout the sampling period, indicating that reducing conditions prevailed. In this well, the 405 presence of dissolved manganese and iron was up to $1.3 \mathrm{mg} \mathrm{L}^{-1}$ and $2.5 \mathrm{mg} \mathrm{L}^{-1}$, respectively, 406 confirming reducing conditions. Downgradient of the focus area, wells OMW5, PZ1, PZ2 and PZ3 407 showed low nitrate values (up to $29.4 \mathrm{mg} \mathrm{L}^{-1}$, Table S2) in all campaigns. Figure 5 shows the evolution of the nitrate concentrations in the wells closer to the barrier (the conventional wells PZ10, PZ4 and PZ11 and the multilevel wells BR1, BR2, BR3, BR4 and BR5) for the three sampling surveys. Overall, there are no significant differences in the nitrate concentration with 411 depth. The nitrate concentrations in these wells increase throughout the sampling period, with median concentrations of approximately $79 \mathrm{mg} \mathrm{L}^{-1}$ (June 2012), $141 \mathrm{mg} \mathrm{L}^{-1}$ (October 2012) and 177 $\mathrm{mg} \mathrm{L}^{-1}$ (March 2013).

414 Regarding multilevel wells located immediately upgradient and downgradient of the PRB, the nitrate 415 concentrations are always higher in piezometers BR1 and BR3, both of which are located to the NW 416 of the barrier, and lower in piezometers BR2, BR4 and BR5, which are located to the SE of the PRB. 417 These results are probably due to the lateral input of water with a high nitrate concentration (the 418 conventional well PZ4, located to the NW of the barrier, has the highest nitrate concentration). 419 Because of this observed lateral input, the percentage of nitrate attenuation due to the barrier was calculated from the nitrate contents by comparing BR1 to BR3 and BR2 to BR4 and BR5. Comparing BR1 to BR3, a slight decrease in the nitrate concentration was observed in June 2012 and October 2012 (16\% decrease) and March 2013 (11\% decrease). Comparing BR2 to BR4 and BR5, a higher decrease in the nitrate concentration was observed in June 2012 (26 to 72\%) and October 2012 424 (30\%), whereas in March 2013, contradictory percentages were obtained (an increase of $10 \%$ 425 between BR2 and BR4 and an 18\% decrease between BR2 and BR5). Therefore, the observed 426 changes in the nitrate concentration from immediately upgradient to downgradient of the PRB 427 suggest the occurrence of nitrate degradation processes related to the ZVI-PRB, although isotope 428 data are required to confirm this hypothesis. No significant differences in nitrite concentrations were 
observed upgradient and downgradient of the barrier, since in most cases, they were below the

430 detection limit $\left(0.01 \mathrm{mg} \mathrm{L}^{-1}\right)$. The ammonium concentration slightly increased from BR2 to BR4 and 431 BR5 in June 2012, but values were always below $0.4 \mathrm{mg} \mathrm{L}^{-1}$. No significant ammonium was detected 432 downgradient of the barrier, indicating that if nitrate was transformed to ammonium through a 433 reaction with the $\mathrm{ZVI}$, it was oxidized again to nitrate or absorbed into soil materials.

434 The wells located far downgradient of the ZVI-PRB (PZ7, PZ8 and PZ9) showed nitrate concentrations 435 ranging from $14 \mathrm{mg} \mathrm{L}^{-1}$ to $80 \mathrm{mg} \mathrm{L}^{-1}$ (Table S2). For the three sampling campaigns, lower values were observed in PZ7 and increased downgradient. This downgradient increase could reflect the contribution of lateral inputs or the fact that the barrier was bypassed. In these points, no significant differences in nitrite and ammonium concentrations were observed.

\subsubsection{Evidence of nitrate reduction: insights from isotope data}

440 The results of the isotopic characterization of the field samples are detailed in the Supplementary 441 Material (Table S3). The samples from the focus zone (MW17) could not be analyzed because the nitrate concentrations were below the detection limit, which is in agreement with the observed reducing conditions and the natural biodegradation of chlorinated solvents described previously by Audí-Miró et al. (2015). Wells OMW5 and PZ2, located upgradient of the PRB, showed isotopic values of approximately $+15 \%$ for $\delta^{15} \mathrm{~N}_{\mathrm{NO} 3}$ and $+11 \%$ for $\delta^{18} \mathrm{O}_{\mathrm{NO} O}$. These high values suggest that natural attenuation of nitrate takes place upgradient of the ZVI-PRB. Audí-Miró et al. (2015) also observed the natural attenuation for chlorinated solvents in these wells.

Figure 6 shows the $\delta^{15} \mathrm{~N}_{\mathrm{NO} 3}$ and $\delta^{18} \mathrm{O}_{\mathrm{NO} 3}$ from the survey of March 2013 at the multilevel wells (BR 1 to 5) and the conventional wells located closer to the PRB (PZ4 and PZ10). The isotopic values of the main potential nitrate sources are represented as well: nitrate fertilizers, ammonium fertilizers, soil nitrate and animal manure or sewage (Vitòria et al., 2004; Kendall et al., 2007; Xue et al., 2009). The range of $\delta^{18} \mathrm{O}$ of nitrate derived from nitrification of ammonium fertilizers, soil nitrogen and/or manure/sewage (from $+1.9 \%$ to $+3.1 \%$ ) was estimated according to Anderson and Hooper (1983)

454 using the range of $\delta^{18} \mathrm{O}_{\mathrm{H} 2 \mathrm{O}}$ measured in groundwater samples (between $-7.6 \%$ and $-5.1 \%$ ). All of the 
samples presented isotope ratios compatible with those for soil organic nitrogen and

456 manure/sewage, with variable degree of denitrification. The nitrogen and oxygen isotope values of 457 the samples located immediately upgradient of the PRB ranged from +6.2 to $+13.9 \%$ or $\delta^{15} \mathrm{~N}$ and 458 from +4.9 to $+9.7 \%$ for $\delta^{18} \mathrm{O}$, whereas the values of the samples located immediately downgradient 459 of the PRB ranged from +13.2 to $+18.1 \%$ for $\delta^{15} \mathrm{~N}$ and from +9.0 to $+12.6 \%$ or $\delta^{18} \mathrm{O}$, except for BR546011 , where low isotope ratios were obtained ( $+9.6 \%$ and $+6.8 \%$, respectively). Taking into account that the PRB is located at a depth of approximately $10 \mathrm{~m}$, a bypass effect probably occurs at the BR511 point, where low isotope ratios were obtained. It is important to note that PZ4 and BR1 showed higher values of $\delta^{15} \mathrm{~N}_{\mathrm{NO} 3}$ and $\delta^{18} \mathrm{O}_{\mathrm{NO} 3}$ than those for BR2, which confirms that both PZ4 and BR1 are affected by a lateral input of groundwater with higher nitrate concentration and different isotope signature. Therefore, in general, higher isotopic values were detected immediately downgradient than immediately upgradient of the PRB, confirming the existence of nitrate attenuation processes.

467 Furthermore, the samples showed a positive correlation $\left(r^{2}=0.89\right)$ between $\delta^{15} \mathrm{~N}_{\mathrm{NO} 3}$ and $\delta^{18} \mathrm{O}_{\mathrm{NO} 3}$ and 468 were aligned following a $\varepsilon^{18} \mathrm{O} / \varepsilon^{15} \mathrm{~N}$ ratio of 0.63 (Fig. 6), which is consistent with denitrification 469 (Kendall et al., 2007) and with the values obtained in the PRB experiments.

We thus assumed the occurrence of combined ZVI-driven nitrate reduction and denitrification. To quantify the efficiency of the ZVI-PRB in removing nitrate, Eq. 7 was applied using the $\varepsilon^{15} \mathrm{~N}$ and $\varepsilon^{18} \mathrm{O}$ values calculated in the PRB batch experiments $\left(\varepsilon^{15} \mathrm{~N}=-29.5 \pm 2.7 \%\right.$ and $\varepsilon^{18} \mathrm{O}=-16.4 \pm 1.1 \%$ ). Since some wells were affected with the lateral input of groundwater contaminated with nitrate with a

474 different isotope signature, two $\delta_{\text {initial }}$ values were used: (1) the initial isotopic composition of the PRB 475 experiment $\left(+8.2 \%\right.$ or $\delta^{15} \mathrm{~N}_{\mathrm{NO} 3}$ and $+5.4 \%$ o for $\left.\delta^{18} \mathrm{O}_{\mathrm{NO} 3}\right)$, which corresponds to water extracted from 476 PZ10, located upgradient of the barrier but not affected by the lateral input of PZ4 (model \% DEN), 477 and (2) the average isotope ratios of the PZ4 and BR1 wells $\left(+12.8 \%\right.$ o for $\delta^{15} \mathrm{~N}_{\mathrm{NO}}$ and $+8.5 \%$ for $478 \delta^{18} \mathrm{O}_{\mathrm{NO} O}$ ), which are clearly affected by the lateral input of PZ4 (model \% DEN Lateral). Figure 8 shows 479 the ranges of percentage of nitrate degradation obtained applying the two models and the isotope 480 signature of the multilevel wells and the PZ4 and PZ10 wells. The \%DEN Lateral model was thus used 
481 for the well BR3, which was clearly affected by the lateral input. The degree of nitrate attenuation in 482 the samples of this well ranged between 10 and 20\%. Similar though slightly lower percentages (5 to $48315 \%)$ were obtained for samples of the BR5 well, for which the \%DEN model was used. Finally, the 484 results from samples from BR4 suggest that this well might also be affected by the lateral input of 485 PZ4, and thus the \%DEN Lateral model was used, obtaining a degree of degradation of approximately 486 $15 \%$.

487

Overall, the nitrate removal percentages calculated using the isotopic model are in agreement with those calculated using the nitrate concentration. On well BR5, this percentage was slightly overestimated using only chemical data, because bypass could only be detected using isotopic data. The isotopic data also allowed the identification of the influence of the lateral input of PZ4 not only on BR3 but also on BR4. Therefore, stable isotopes of dissolved nitrate are powerful tools to assess

492 the efficacy of the barrier for nitrate removal.

493 For further quantitative evaluation of the effect of the ZVI-PRB on the nitrate fate, by means of the 494 data obtained in the laboratory experiments, the contribution of the purely abiotic ZVI-driven 495 reaction in overall nitrate consumption was calculated using the equation proposed by Van 496 Breukelen (2007) for estimating the distribution (F) of two competing pathways based on the twodimensional isotopes approach (Eq. 11):

499 where $\varepsilon^{18} \mathrm{O}_{A} / \varepsilon^{15} \mathrm{~N}_{\mathrm{A}}$ corresponds to the ratio of 0.63 obtained for the wells located immediately 500 upgradient and downgradient of the PRB (Fig. 6). The $\varepsilon^{18} \mathrm{O}$ and $\varepsilon^{15} \mathrm{~N}$ values obtained in the laboratory 501 experiments were used for pathway 1 (purely abiotic ZVI-PRB driven nitrate reduction, i.e., MQ 502 experiment, Table 1) and pathway 2 (denitrification, i.e., values obtained by Eq. 10, Table 1). The 503 results show that approximately $30 \%$ of the nitrate consumption was related to the purely abiotic 504 nitrate reduction by the ZVI included in the PRB. 
Overall, the isotopic results confirm that nitrate reduction is taking place in the barrier, though it has

506 a limited effect (maximum attenuation degree of $15-20 \%$ ). This result is in agreement with the 507 previous results of Audí-Miró et al. (2015), in which the effectiveness of the ZVI-PRB to reduce 508 chlorinated solvents was tested using isotopic tools and was demonstrated to be even less efficient than for nitrate (maximum of 10\%). The O-N slope of field values fit the expected slope obtained in the laboratory experiments well, indicating that isotopes are an excellent tool to determine the efficacy of the ZVI-PRB at the field scale.

\section{Conclusions}

513 In laboratory experiments with sterilized ZVI and synthetic nitrate solutions, ZVI induced nitrate 514 reduction, mainly releasing ammonium to solution (after 7 days, ammonium accounted for $70-80 \%$ 515 of nitrate reduction). For assessing the fate of nitrate in the contaminated site of Granollers, where a 516 ZVI-PRB was installed, batch experiments were also performed using ZVI and groundwater from the 517 study area. In these experiments, the main final product was also ammonium (80-100\%). The faster 518 nitrate removal rates of the latter suggest denitrification processes in addition to the ZVI-driven 519 purely abiotic nitrate reduction. Isotopic fractionation associated to ZVI-induced nitrate attenuation 520 processes was determined for the first time. The significant statistical difference between the 521 isotope $\varepsilon^{18} O / \varepsilon^{15} \mathrm{~N}$ ratios obtained for the experiments with purely abiotic solutions $(0.43 \pm 0.02)$ and

522 for the PRB experiment $(0.54 \pm 0.07)$ shows the potential for the use of this approach to distinguish 523 ZVI-driven nitrate reduction and additional degradation of nitrate by the action of autochthonous bacteria in field sites where ZVI-PRBs are installed. Data obtained from the laboratory experiments were used for assessing the fate of nitrate in the study area. Combining chemical and isotope data, it was demonstrated that the ZVI-PRB installed in the study area locally induced nitrate attenuation, though the barrier had a limited effect (less than 15-20\%). As Audí-Miró et al. (2015) noted for 528 chlorinated solvents, this low efficiency in nitrate removal was probably related to the non-optimal 529 design of the PRB, including a ZVI amount (3\%) that was too low and an insufficient length of the 530 PRB, which was responsible for the bypass occurrence. Further evaluation of the fate of ammonium 
downgradient of the ZVI-PRB is required since no ammonium was detected in groundwater.

532 Laboratory experiments can be performed to assess the potential retention of the generated

533 ammonium by the aquifer materials through ion exchange and/or adsorption. Further work is

534 required to identify the reaction responsible for the additional nitrate removal in experiments with

$535 \quad$ ZVI and groundwater from the field site and to study the denitrifying microbial community developed

536 around the ZVI-PRB. Overall, this study highlights the potential of isotope tools for determining the

537 efficacy of nitrate removal by ZVI-PRBs at the field scale. This information might be crucial for

538 mitigating existing pollution in water resources and improving remediation actions.

\section{Acknowledgments}

541 This work has been financed by the projects: REMEDIATION (CGL2014-57215-C4) and PACE-ISOTEC

542 (CGL2017-87216-C4-1-R), financed by the Spanish Government and AEI/FEDER from the EU, 543 respectively, and MAG (2017 SGR 1733) from the Catalan Government. We would like to thank the

544 CCiT of the Universitat de Barcelona for the analytical support. We thank the editor and four 545 anonymous reviewers for comments that improved the quality of the manuscript.

\section{References}

547 Alowitz, M.J., Scherer, M.M. (2002). Kinetics of nitrate, nitrite, and $\mathrm{Cr}(\mathrm{VI})$ reduction by iron metal. 548 Environm. Sci. Technol. 36, 299-306.

549 An, Y., Li, T.L., Jin, Z.H., Dong, M.Y., Li, Q.Q. (2009). Decreasing ammonium generation using 550 hydrogenotrophic bacteria in the process of nitrate reduction by nanoscale zero-valent iron. Sci. 551 Total Environ. 407, 5465-5470.

552 Anderson, K.K., Hooper, A.B., (1983). $\mathrm{O}_{2}$ and $\mathrm{H}_{2} \mathrm{O}$ are each the source of $\mathrm{O}$ in $\mathrm{NO}_{2}$ produced from $\mathrm{NH}_{3}$ 553 by Nitrosomas: ${ }^{15} \mathrm{~N}-\mathrm{NMR}$ evidence. FEBS Lett. $64,236-240$.

554 Aravena, R., Robertson, W.D. (1998). Use of multiple isotope tracers to evaluate denitrification in 555 ground water: Study of nitrate from a large-flux septic system plume. Ground Water 36, 975-982. 
556 Audí-Miró, C., Cretnik, S., Torrentó, C., Rosell, M., Shouakar-Stash, O., Otero, N., Palau, J., Elsner, M., 557 Soler, A. (2015). C, Cl and $\mathrm{H}$ compound specific isotope analysis to assess natural versus $\mathrm{Fe}(0)$ barrier558 induced degradation of chlorinated ethenes at a contaminated site. J. Hazar. Mater. 299, 747-754.

559 Brunauer, S., Emmet, P. H., Teller, E. (1938). Adsorption of gases on multimolecular layers. J. Am. 560 Chem. Soc. 60, 309-319.

561 Buchwald, C., Grabb, K., Hansel, C.M., Wankel, S.D. (2016). Constraining the role of iron in 562 environmental nitrogen transformations: dual stable isotope systematics of abiotic $\mathrm{NO}_{2}{ }^{-}$reduction by $563 \mathrm{Fe}(\mathrm{II})$ and its production of $\mathrm{N}_{2} \mathrm{O}$. Geochim. Cosmochim. Ac. 186, 1-12.

564 Casciotti, K.L., Sigman, D.M., Hastings, M.G., Böhlke, J.K., Hilkert, A. (2002). Measurement of the 565 oxygen isotopic composition of nitrate in seawater and freshwater using the denitrifier method. 566 Anal. Chem. 74, 4905-4912.

567 Chen, Y.M., Li, C.W., Chen, S.S. (2005). Fluidized zero valent iron bed reactor for nitrate removal. 568 Chemosphere 59, 753-759.

569 Cheng, I.F., Muftikian, R., Fernando, Q., Korten, N. (1997). Reduction of nitrate to ammonia by zero570 valent iron. Chemosphere 35, 2689-2695.

571 Choe, S., Chang, Y.Y., Hwang, K.Y., Khim, J. (2000). Kinetics of reductive denitrification by nanoscale 572 zero-valent iron. Chemosphere 41, 1307-1311.

573 Choe, S., Liljestrand, H.M., Khim, J. (2004). Nitrate reduction by zero-valent iron under different pH 574 regimes. Appl. Geochem. 19, 335-342.

575 Coplen, T.B. (2011). Guidelines and recommended terms for expression of stable-isotope-ratio and 576 gas-ratio measurement results. Rapid Commun. Mass Sp. 25, 2538-2560.

577 Dähnke, K., Thamdrup, B. (2016). Isotope fractionation and isotope decoupling during anammox and 578 denitrification in marine sediments. Limnol. Oceanogr. 61, 610-624.

579 Daniels, L., Belay, N., Rajagopal, P., Weimer, J. (1987). Bacterial methanogenesis and the growth of $580 \mathrm{CO}_{2}$ with elemental iron as the sole source of electrons. Science $237,509-511$.

581 Da Silva, M.L.B., Johnson, R.L., Alvarez, P.J.J. (2007). Microbial characterization of groundwater 582 undergoing treatment with a permeable reactive iron barrier. Environ. Eng. Sci. 24, 1122-1127. 
583 Dayan, H., Abrajano, T., Sturchio, N.C., Winsor, L. (1999). Carbon isotopic fractionation during 584 reductive dehalogenation of chlorinated ethenes by metallic iron. Org. Geochem. 30, 755-763.

585 Della Rocca, C., Belgiorno, V., Meric, S. (2006). An heterotrophic/autotrophic denitrification (HAD) 586 approach for nitrate removal from drinking water. Process. Biochem. 41, 1022-1028.

587 Della Rocca, C., Belgiorno, V., Meric, S. (2007). Overview of in-situ applicable nitrate removal 588 processes. Desalination 204, 46-62.

589 Dejournett, T.D., Alvarez, P.J. (2000). Combined microbial-Fe (0) treatment system to remove nitrate 590 from contaminated groundwater. Biorem. J. 4, 149-154.

591 Epstein, S., Mayeda, T. (1953). Variation of $\mathrm{O}^{18}$ content of waters from natural sources. Geochim. 592 Cosmochim. Ac. 4, 213-224.

593 Flury, B., Eggenberger, U., Mäder, U. (2009). First results of operating and monitoring an innovative 594 design of a permeable reactive barrier for the remediation of chromate contaminated groundwater. 595 Appl. Geochem. 24, 687-696.

596 Ginner, J.L., Alvarez, P.J., Smith, S.L., Scherer, M.M. (2004). Nitrate and nitrite reduction by Fe0: 597 influence of mass transport, temperature, and denitrifying microbes. Environm. Eng. Sci. 21, 219-229.

598 Grabb, K. C., Buchwald, C., Hansel, C.M., Wankel, S.D. (2017). A dual nitrite isotopic investigation of 599 chemodenitrification by mineral-associated Fe (II) and its production of nitrous oxide. Geochim. 600 Cosmochim. Ac., 196, 388-402.

601 Granger, J., Sigman, D.M., Needoba, J.A., Harrison, P.J. (2004). Coupled nitrogen and oxygen isotope 602 fractionation of nitrate during assimilation by cultures of marine phytoplankton. Limnol. Oceanogr. $60349,1763-1773$

604 Granger, J., Sigman, D.M., Lehmann, M.F., Tortell, P.D. (2008). Nitrogen and oxygen isotope 605 fractionation during dissimilatory nitrate reduction by denitrifying bacteria. Limnol. Oceanogr. 53, $606 \quad 2533-2545$.

607 Grau-Martínez, A., Torrentó, C., Carrey, R., Rodríguez-Escales, P., Domènech, C., Ghiglieri, G., Soler, 608 A., Otero, N. (2017). Feasibility of two low-cost organic substrates for inducing denitrification in 609 artificial recharge ponds: Batch and flow-through experiments. J. Contam. Hydrol. 198, 48-58. 
610 Grau-Martínez, A., Folch, A., Torrentó, C., Valhondo, C., Barba, C., Domènech, C., Soler, A., Otero, N. 611 (2018). Monitoring induced denitrification during managed aquifer recharge in an infiltration pond. J. 612 Hydrol. 561, 123-135.

613 Gu, B., Watson, D.B., Phillips, D.H., Liang, L. (2002a). Biogeochemical, mineralogical, and hydrological 614 characteristics of an iron reactive barrier used for treatment of uranium and nitrate, In: D.L. Naftz, S. 615 J. Morrison, J.A. Davis, C.C. Fuller (Eds.), Groundwater remediation of trace metals, radionuclides, 616 and nutrients with Permeable Reactive Barriers. Academic Press, New York, pp. 305-342.

617 Gu, B., Watson, D.B., Wu, L., Phillips, D.H., White, C., Zhou, J.Z. (2002b). Microbiological 618 characteristics in a zero-valent iron reactive barrier. Environ. Monit. Assess. 77, 293-309.

619 Hosseini, S.M., Altaie-Ashtiani, B., Kholghi, M. (2011). Bench-scaled nano-FeO permeable reactive 620 barrier for nitrate removal. Ground Water Monit. R. 31 (4), 82-94

621 Hosseini, S.M., Tosco, T. (2015). Integrating NZVI and carbon substrates in a non-pumping reactive 622 wells array for the remediation of a nitrate contaminated aquifer. J. Contam. Hydrol. 179, 182-195.

623 Hosseini, S.M., Tosco, T., Ataie-Ashtiani, B., Simmons, C.T. (2018). Non-pumping reactive wells filled 624 with mixing nano and micro zero-valent iron for nitrate removal from groundwater: Vertical, 625 horizontal, and slanted wells. J. Contam. Hydrol. 210, 50-64.

$626 \mathrm{Hu}$, H.-Y., Naohiro, G., Koichi, F. (2001) Effect of pH on the reduction of nitrite in water by metallic 627 iron. Water Res. 35, 2789-2793.

628 Huang, Y.H., Zhang, T.C. (2004). Effects of low pH on nitrate reduction by iron powder. Water Res. 38, $629 \quad 2631-2642$.

630 Huang, C.P., Wang, H.W., Chiu, P.C. (1998). Nitrate reduction by iron at near neutral pH. J. Environ. 631 Engineer. ASCE 128, 604-611.

632 Huang, G., Huang, Y., Hu, H., Liu, F., Zhang, Y., Deng, R. (2015). Remediation of nitrate-nitrogen 633 contaminated groundwater using a pilot-scale two-layer heterotrophic-autotrophic denitrification 634 permeable reactive barrier with spongy iron/pine bark. Chemosphere 130, 8-16.

635 Hwang, Y.H., Kim, D., Shin, H. (2011). Mechanism study of nitrate reduction by nano zero valent iron. 636 J. Hazard. Mater. 185, 1513-1521. 
637 Jamieson, J., Prommer, H., Kaksonen, A.H., Sun, J., Siade, A. J., Yusov, A., Bostick, B. (2018). 638 Identifying and quantifying the intermediate processes during nitrate-dependent iron (II) oxidation. 639 Environm. Sci. Technol. 52, 5771-5781.

640 Johnson, T.L., Scherer, M.M., Tratnyek, P.G. (1996) Kinetics of halogenated organic compound 641 reduction by iron metal. Environ. Sci. Technol. 30, 2634-2640.

642 Johnson, R., Tratnyek, P. (2008). Remediation of Explosives in Groundwater Using a Zero-Valent Iron 643 Permeable Reactive Barrier. ESTCP Project ER-0223, Oregon Health and Science University, Portland.

644 Kamolpornwijit, W., Liang, L., West, O.R., Moline, G.R., Sullivan, A.B. (2003). Preferential flow path 645 development and its influence on long-term PRB performance: column study. J. Contam. Hydrol. 66, $646 \quad 161-178$.

647 Kendall, C., Elliott, E.M., Wankel, S.D. (2007). Tracing anthropogenic inputs of nitrogen to 648 ecosystems. In: Michener, R.H., Lajtha, K. (Eds.), Stable isotopes in Ecology and Environmental 649 Science. Blackwell Publishing, pp. 375-449.

650 Khan, F.I., Husain, T., Hejazi, R. (2004). An overview and analysis of site remediation technologies. J. 651 Envirn. Manage. 71, 95-122.

652 Knöller, K., Vogt, C., Haupt, M., Feisthauer, S., Richnow, H.H. (2011). Experimental investigation of 653 nitrogen and oxygen isotope fractionation in nitrate and nitrite during denitrification. 654 Biogeochemistry 103, 371-384.

655 Kraft, B., Strous, M., Tegetmeyer, H.E. (2011). Microbial nitrate respiration - genes, enzymes and 656 environmental distribution. J. Biotechnol. 155, 104-117.

657 Liang, L., Moline, G.R., Kamolpornwijit, W., West, O.R. (2005). Influence of hydrogeochemical 658 processes on zero-valent iron reactive barrier performance: A field investigation. J. Contam. Hydrol. $65978,291-312$.

660 Liu, Y.S., Ying, G.G., Shareef, A., Kookana, R.S. (2013). Biodegradation of three selected 661 benzotriazoles in aquifer materials under aerobic and anaerobic conditions. J. Contam. Hydrol. 151, 662 131-139.

663 Mariotti, A., Landreau, A., Simon, B. (1988). ${ }^{15} \mathrm{~N}$ isotope biogeochemistry and natural denitrification 664 process in groundwater application to the chalk aquifer of northern France. Geochim. Cosmochim. 665 Ac. 52, 1869-1878. 
666 Matheson, L.J., Tratnyek, P.G. (1994). Reductive dehalogenation of chlorinated methanes by iron 667 metal. Environ. Sci. Technol. 28, 2045-2053.

668 Mcllvin, M.R., Altabet, M.A. (2005). Chemical conversion of nitrate and nitrite to nitrous oxide for 669 nitrogen and oxygen isotopic analysis in freshwater and seawater. Anal. Chem. 77, 5589-5595.

670 Miehr, R., Tratnyek, P.G., Bandstra, J.Z., Scherer, M.M., Alowitz, M.J., Bylaska, E.J. (2004). Diversity of 671 contaminant reduction reactions by zerovalent iron: Role of the reductate. Environm. Sci. Technol. $67238,139-147$.

673 Morrison, S. J.; Carpenter, C. E.; Metzler, D. R.; Bartlett, T. R.; Morris, S. A. (2002). Desing and 674 performance of a Permeable Reactive Barrier for containment of uranium, arsenic, selenium, 675 vanadium, molybdenum and nitrate at Monticello, Utah. In: Naftz, D.L., Morrison, S.J., Fuller, C.C., 676 Davis, J.A. (Eds.) Handbook of groundwater remediation using Permeable Reactive Barriers. 677 Applications to radionuclides, trace Metals, and nutrients. Academic Press, New York, pp. 371-399.

678 O'Hannesin, S.F., Gillham, R.W. (1998). Long-term performance of an in situ "iron wall" for 679 remediation of VOCs. Ground Water 36, 164-170.

680 Phillips, D.H. (2010). Permeable reactive barriers: a sustainable technology for cleaning contaminated 681 groundwater in developing countries. Desalination 251, 352-359.

682 Rajagopal, B., LeGall, J. (1989). Utilization of cathodic hydrogen by hydrogen oxidizing bacteria. Appl. 683 Microbiol. Biotechnol. 31, 406-412.

684 Reardon, E.J. (1995). Anaerobic corrosion of granular iron: measurement and interpretation of 685 hydrogen evolution rates. Environ. Sci. Technol. 29, 2936-294

686 Ritter, K., Odziemskowski, M.S., Gillham, R.W. (2002). An in situ study of the role of surface films on 687 granular iron in the permeable iron wall technology. J. Contam. Hydrol. 55, 87-111.

688 Rivett, M.O., Buss, S.R., Morgan, P., Smith, J.W.N., Bemment, C.D. (2008). Nitrate attenuation in 689 groundwater: a review of biogeochemical controlling processes. Water Res. 42, 4214-4232.

690 Rodríguez-Maroto, J.M., García-Herruzo, F., García-Rubio, A., Gómez-Lahoz, C., Vereda-Alonso, C. 691 (2009). Kinetics of the chemical reduction of nitrate by zero-valent iron. Chemosphere 74, 804-809.

692 Ryabenko, E., Altabet, M.A., Wallace, D.W.R. (2009). Effect of chloride on the chemical conversion of 693 nitrate to nitrous oxide for $\delta^{15} \mathrm{~N}$ analysis. Limnol. Oceanogr. 7, 545-552. 
694 Shin, K., Cha, D.K. (2008). Microbial reduction of nitrate in the presence of nanoscale zero-valent 695 iron. Chemosphere, 72, 257-262.

696 Sigman, D.M., Granger, J., DiFiore, P.J., Lehmann, M.M., Ho, R., Cane, G., van Geen, A. (2005). 697 Coupled nitrogen and oxygen isotope measurements of nitrate along the eastern North Pacific 698 margin. Global Biogeochem. Cy. 19.

699 Slater, G.F., Lollar, B.S., King, A., O'Hannesin, S. (2002). Isotopic fractionation during reductive 700 dechlorination of trichloroethene by zero-valent iron: influence of surface treatment. Chemosphere $701 \quad 49,587-596$.

702 Smith, R.L., Kent, D.B., Repert, D.A., Böhlke, J.K. (2017). Anoxic nitrate reduction coupled with iron 703 oxidation and attenuation of dissolved arsenic and phosphate in a sand and gravel aquifer. Geochim. 704 Cosmochim. Ac. 196, 102-120.

705 Su, C., Puls, R.W. (2004). Significance of iron (II, III) hydroxycarbonate green rust in arsenic 706 remediation using zero valent iron in laboratory column test. Environ. Sci. Technol. 38, 5224-5231.

707 Suzuki, T., Moribe, M., Oyama, Y., Niinaem M. (2012). Mechanism of nitrate reduction by zero-valent 708 iron: Equilibrium and kinetics studies. Chem. Engineer. J. 183, 271-277.

709 Till, B.A., Weathers, J.L., Alvarez, J.J.P. (1998). Fe(0)-Supported autotrophic denitrification. Environ. 710 Sci. Technol. 32, 634-639.

711 Torrentó, C., Cama, J., Urmeneta, J., Otero, N., Soler, A. (2010). Denitrification of groundwater with 712 pyrite and Thiobacillus denitrificans. Chemical Geology, 278, 80-91.

713 Torrentó, C., Palau, J., Rodríguez-Fernández, D., Heckel, B., Meyer, A., Domènech, C., Rosell, M., 714 Soler, A., Elsner, M., Hunkeler, D. (2017). Carbon and chlorine isotope fractionation patterns 715 associated with different engineered chloroform transformation reactions. Environ. Sci. Technol. 51, $716 \quad 6174-6184$

717 Toyoda, S., Mutobe, H., Yamagishi, H., Yoshida, N., Tanji, Y. (2005). Fractionation of $\mathrm{N}_{2} \mathrm{O}$ isotopomers 718 during production by denitrifier. Soil Biol. Biochem. 37, 1535-1545.

719 Tratnyek, P.G., Scherer, M.M., Johnson, T.L., Matheson, L.J. (2003). Permeable reactive barriers of 720 iron and other zero-valent metals. In: Tarr, M.A. (Ed.) Chemical degradation methods for wastes and 721 pollutants: Environmental and industrial applications. CRC Press, p.p. 371-422. 
U.S. EPA (2002). Field Applications of In Situ Remediation Technologies: Permeable Reactive Barriers. U.S. Environmental Protection Agency, Office of Solid Waste and Emergency Response, Washington, DC.

725

726 727

Van Breukelen, B.M. (2007). Extending the Rayleigh equation to allow competing isotope fractionating pathways to improve quantification of biodegradation. Environ. Sci. Technol. 41, 40044010.

Vitòria, L., Otero, N., Canals, A., Soler, A. (2004). Fertilizer characterization: isotopic data (N, S, O, C and Sr). Environ. Sci. Technol. 38, 3254-3262.

Westerhoff, P., James, J. (2003). Nitrate removal in zero-valent iron packed columns. Water Res. 37, 1818-1830.

Wilkin, R.T., Acree, S.D., Ross, R.R., Puls, R.W., Lee, T.R., Woods, L.L. (2014). Fifteen-year assessment of a permeable reactive barrier for treatment of chromate and trichloroethylene in groundwater. Sci. Total Environ. 468-469, 186-194.

Wunderlich, A., Meckenstock, R., Einsiedl, F. (2012). Effect of different carbon substrates on nitrate stable isotope fractionation during microbial denitrification. Environ. Sci. Technol. 46, 4861-4868.

Wunderlich, A., Meckenstock, R.U., Einsiedl, F. (2013). A mixture of nitrite-oxidizing and denitrifying microorganisms affects the $\delta^{18} \mathrm{O}$ of dissolved nitrate during anaerobic microbial denitrification depending on the $\delta^{18} \mathrm{O}$ of ambient water. Geochim. Cosmochim. Ac. 119, 31-45.

Xu, C., Wang, X., An, Y., Yue, J., Zhang, R. (2018). Potential electron donor for nanoiron supported hydrogenotrophic denitrification: $\mathrm{H}_{2}$ gas, $\mathrm{Fe} 0$, ferrous oxides, $\mathrm{Fe}^{2+}(\mathrm{aq})$, or $\mathrm{Fe}^{2+}(\mathrm{ad})$ ?. Chemosphere, 202, 644-650.

Xue, D., Botte, J., De Baets, B., Accoe, F., Nestler, A., Taylor, P., Van Cleemput, O., Berglund, M., Boeckkx, P. (2009). Present limitations and future prospects of stable isotopes methods for nitrate source identification in surface and groundwater. Water Res. 43, 1159-1170.

Yabusaki, S., Cantrell, K., Sass, B., Steefel, C. (2001). Multicomponent reactive transport in an in situ zero-valent iron cell. Environm. Sci. Technol. 35, 1493-1503.

Yang, S.-C., Lei, M., Chen, T.-B., Li, X.-Y., Liang, Q., Ma, C. (2010). Application of zerovalent iron (Fe(0)) to enhance degradation of $\mathrm{HCHs}$ and $\mathrm{DDX}$ in soil from a former organochlorine pesticides manufacturing plant. Chemosphere 79, 727-732. 
751 Yang, G.C.C., Lee, H.L. (2005). Chemical reduction of nitrate by nanosized iron: kinetics and pathways. 752 Water Res. 39, 884-894.

753 Zhang, Y., Douglas, G.B., Pu, L., Zhao, Q., Tang, Y., Xu, W., Luo, B., Hong, W., Cui, L., Ye, Z. (2017). 754 Zero-valent iron-facilitated reduction of nitrate: Chemical kinetics and reaction pathways. Sci. Total 755 Environm. 598, 1140-1150.

756 Zhang, Y., Douglas, G. B., Kaksonen, A. H., Cui, L., Ye, Z. (2019). Microbial reduction of nitrate in the 757 presence of zero-valent iron. Sci. Total Environm. 646, 1195-1203. 


\section{Figure captions}

2 Figure 1. Map of the study site. The location of the wells installed along Can Ninou Creek, 3 the location of the ZVI-PRB, and the distribution of the multilevel wells around the ZVI-PRB, 4 as well as the piezometric surfaces and groundwater flow lines, are represented. Cross 5 section along the creek from the source area to $1000 \mathrm{~m}$ downstream. The lithology and the 6 screened interval of each well is exposed, as well as the water table indicated by the 7 blue triangles. Modified from Audi-Miró et al. (2015).

8 Figure 2. Evolution of In $\left(\mathrm{C} / \mathrm{C}_{0}\right)$ for both nitrate and ammonium over time in all of the batch 9 experiments. The linear regression lines and high correlation values $\left(R^{2}\right)$ evidenced pseudo10 first-order kinetics.

11 Figure 3. $\delta^{18} \mathrm{O}(\mathrm{A})$ and $\delta^{15} \mathrm{~N}(\mathrm{~B})$ of nitrate against the natural logarithm of the nitrate 12 concentration in the batch experiments. The slopes of the regression lines represent $(\alpha-1)$, 13 the isotopic fractionation for $\mathrm{N}$ and $\mathrm{O}$.

14 Figure 4. $\Delta \delta^{15} \mathrm{~N}$ vs. $\Delta \delta^{18} \mathrm{O}$ of nitrate for the batch experiments. The error bars show the 15 uncertainty in the isotope measurements.

16 Figure. 5. Nitrate concentrations by depth in the surroundings of the PRB. The different depths of the multilevel wells are shown, as well as those of two conventional wells located immediately upgradient (PZ10) and downgradient (PZ11) of the PRB (blue rectangle). The well PZ4, located in the NW end of the PRB, is also shown. The size of the symbols is proportional to the corresponding nitrate concentration value. Reference concentration 21 values are shown for comparison.

22 Figure 6. $\delta^{15} \mathrm{~N}_{\mathrm{NO} 3}$ and $\delta^{18} \mathrm{O}_{\mathrm{NO} 3}$ in groundwater samples collected in March 2013 for the 23 multilevel wells and two conventional wells located immediately upgradient of the PRB (PZ4 24 and PZ10), as well as the isotope composition of the main potential nitrate sources: 
25 fertilizers, soil nitrate and animal manure or sewage.

26 Figure 7. $\delta{ }^{15} \mathrm{~N}_{\mathrm{NO} 3}$ vs. $\delta^{18} \mathrm{O}_{\mathrm{NO} 3}$ in groundwater samples collected in March 2013 for the 27 multilevel wells and for two conventional wells located immediately upgradient of the PRB 28 (PZ4 and PZ10). The size of the bubbles is proportional to the nitrate concentration. The 29 denitrification models calculated with the Rayleigh equation using the isotopic fractionation 30 obtained in the PRB experiment and two different initial values, one affected by the lateral 31 input of PZ4 (\% DEN Lateral) and one not affected (\% DEN), are also shown.

\section{Table captions}

33 Table 1. Obtained $\mathrm{N}$ and $\mathrm{O}$ isotope fractionation values $\left(\varepsilon^{15} \mathrm{~N}\right.$ and $\left.\varepsilon^{18} \mathrm{O}\right)$ and isotope ratios $34\left(\varepsilon^{18} \mathrm{O} / \varepsilon^{15} \mathrm{~N}\right)$ for the laboratory experiments 


\section{Figure 1}

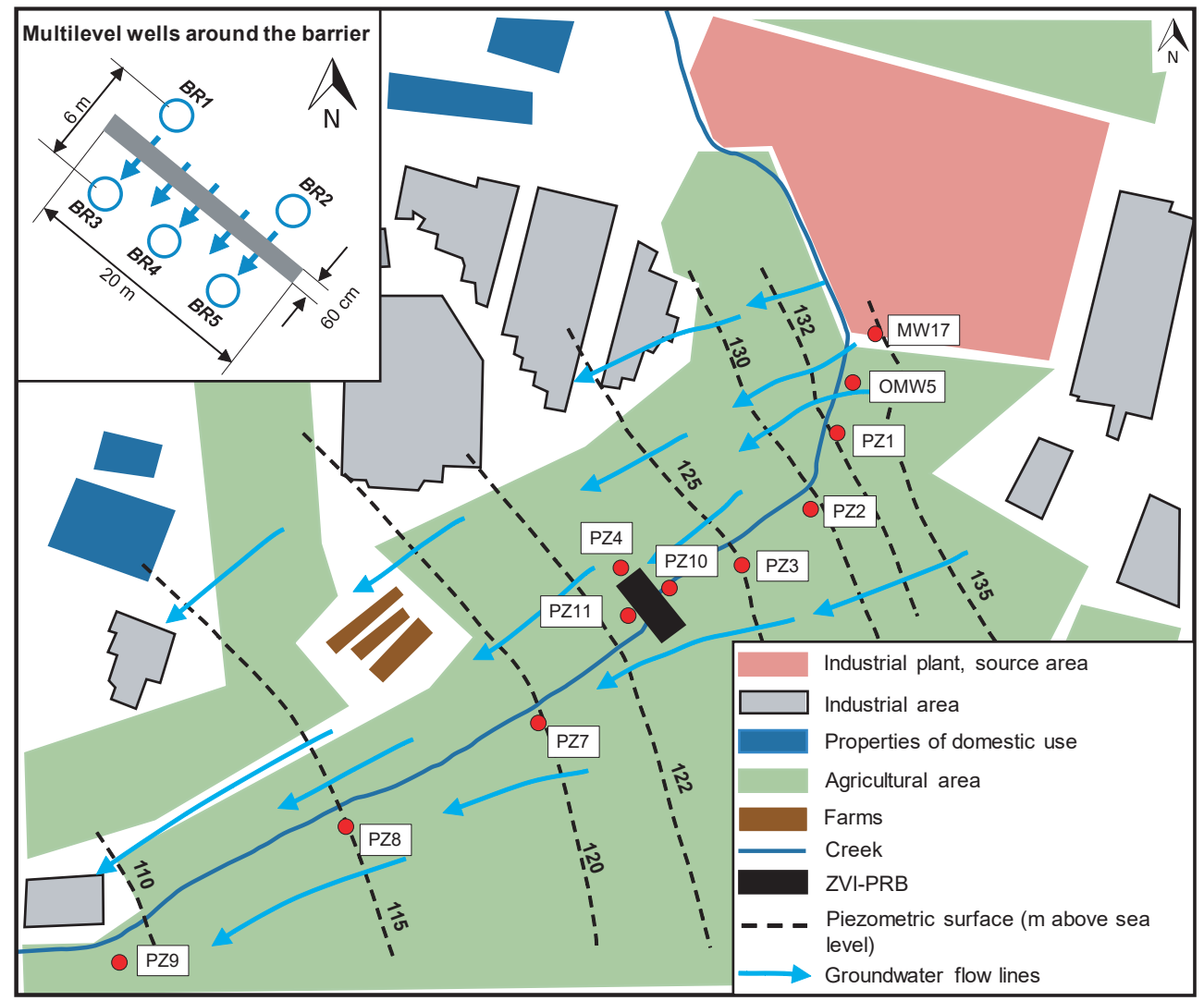

व)

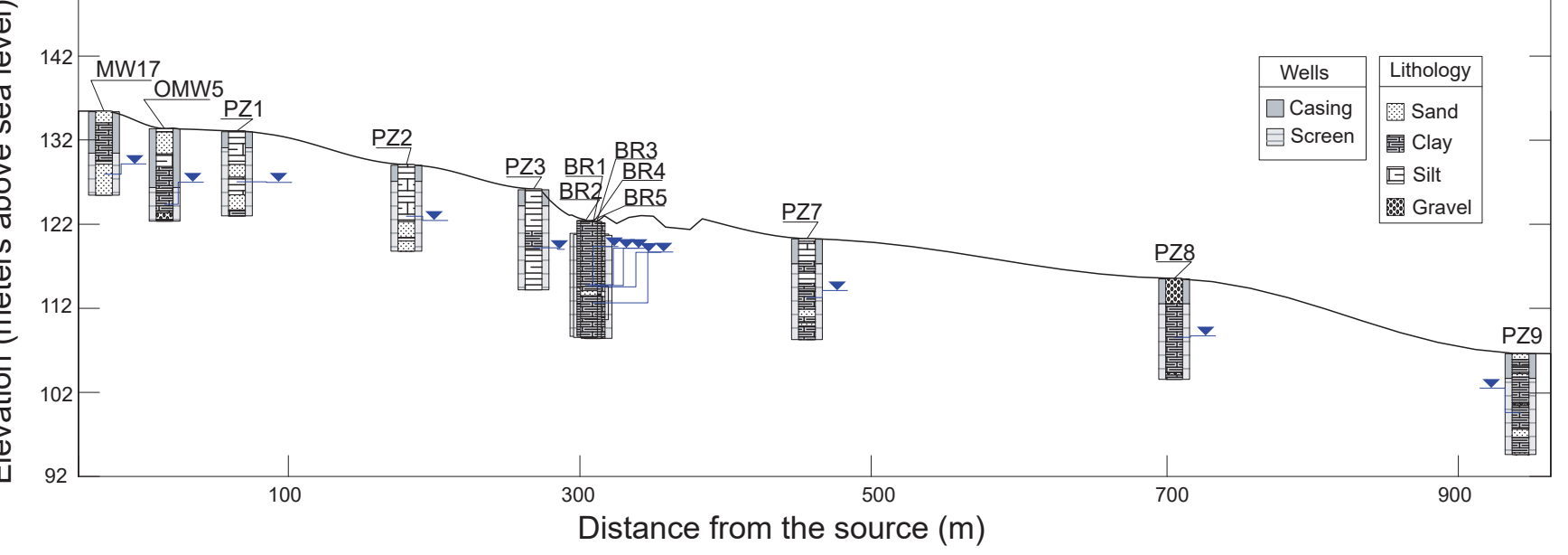


Figure 2

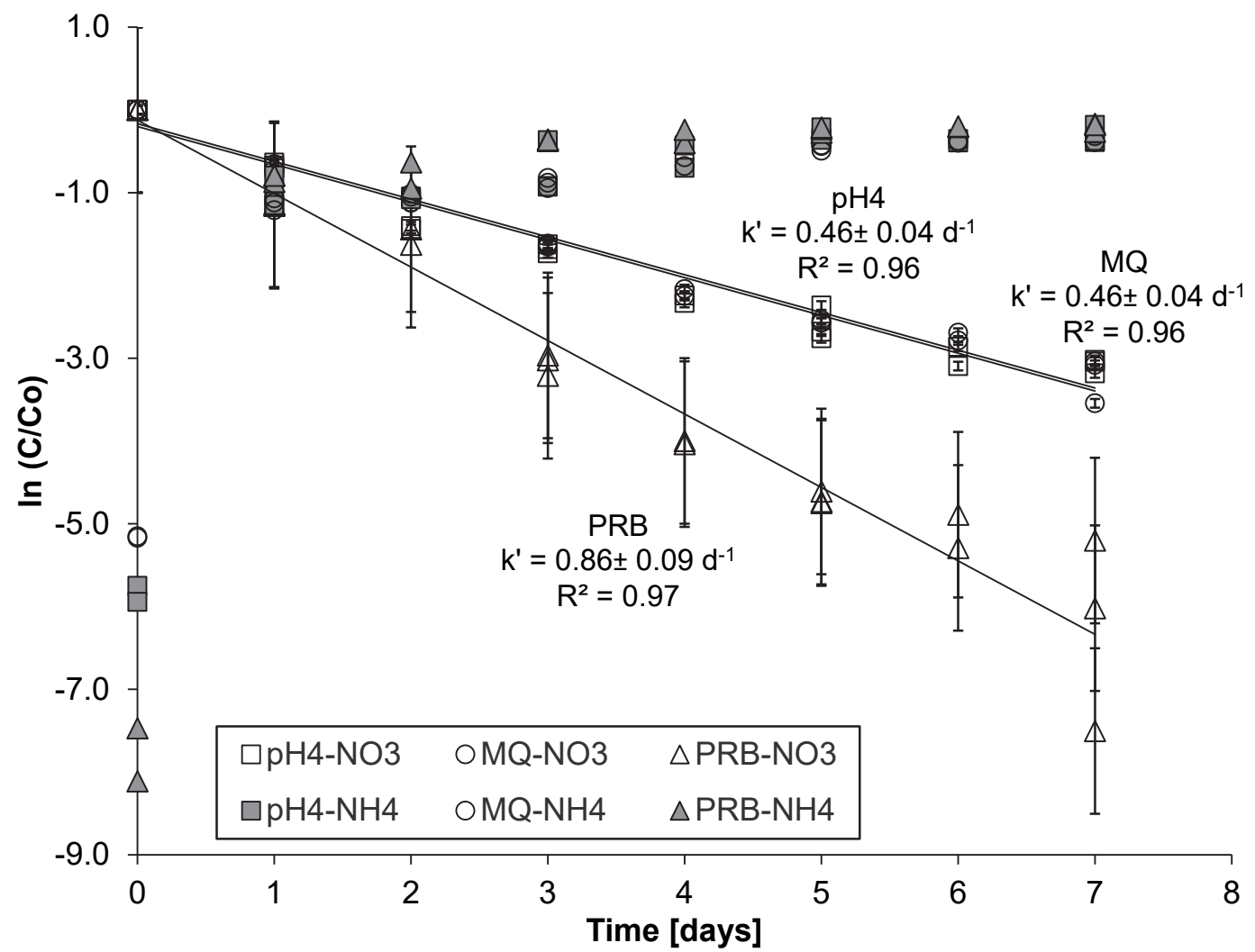


Figure 3

A

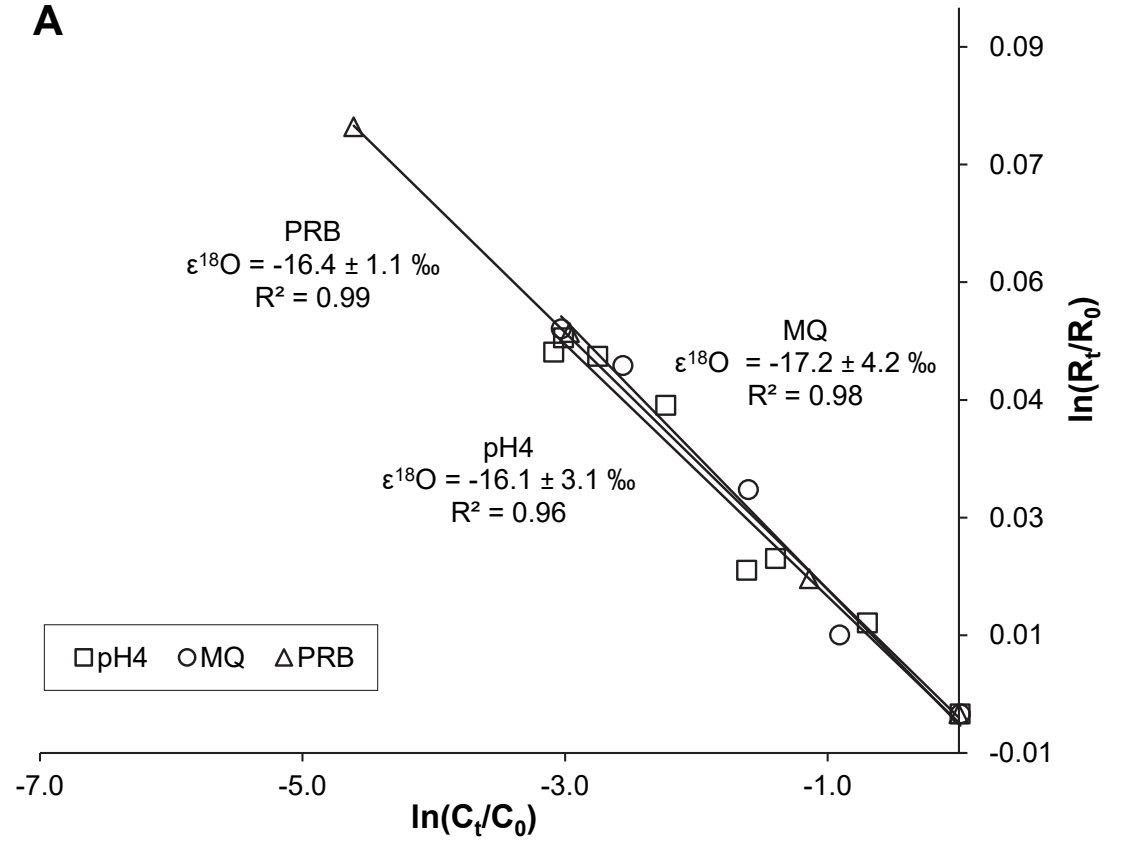

B

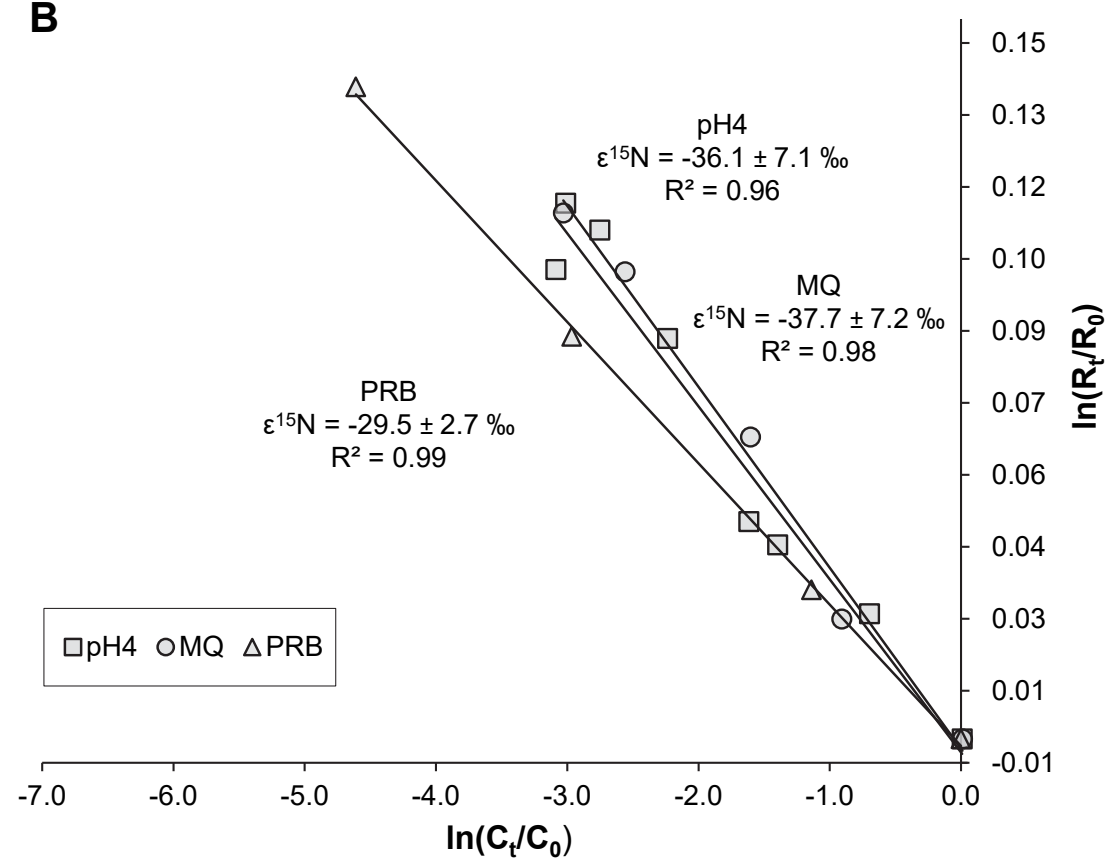


Figure 4

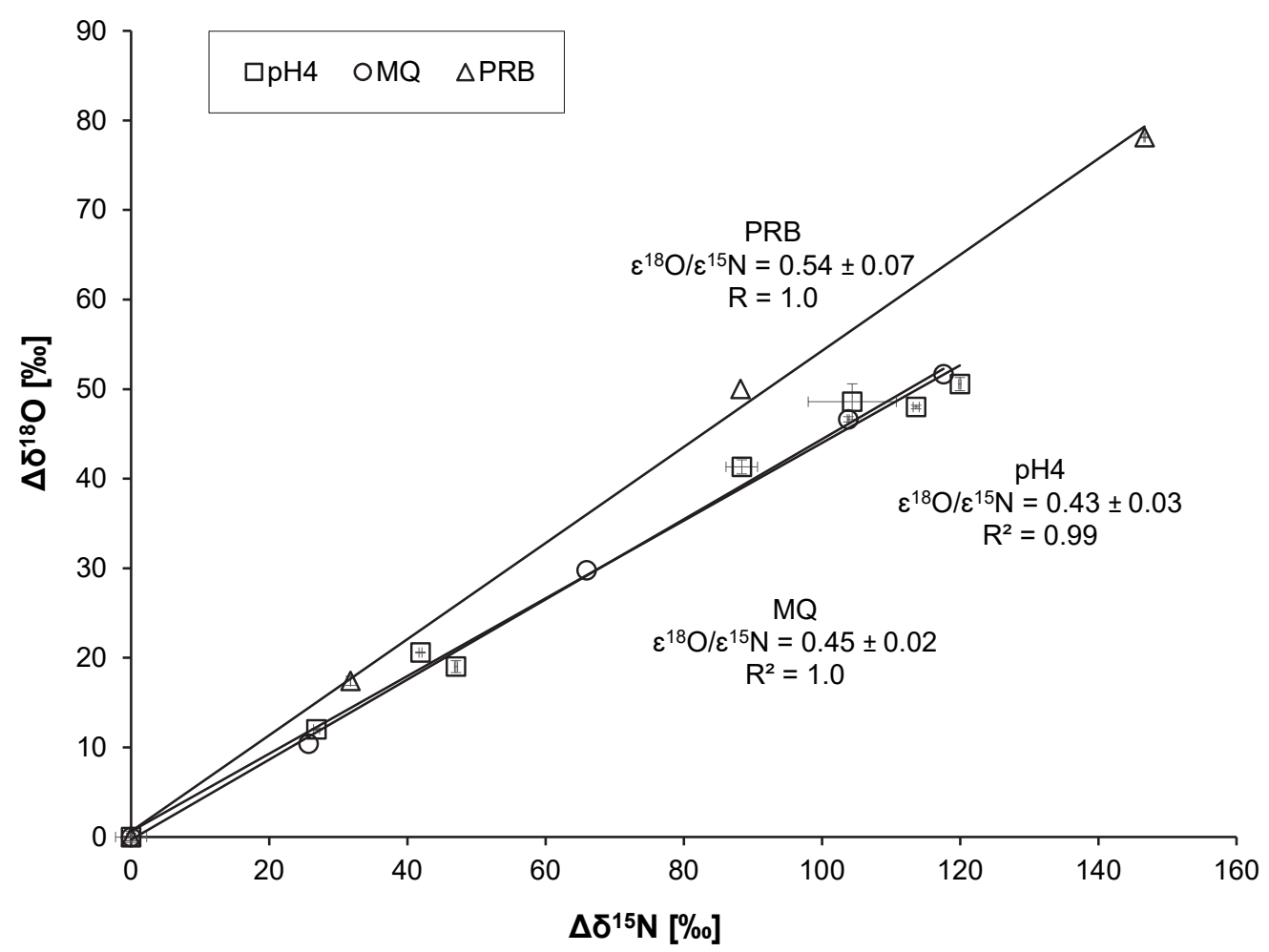


Figure 5

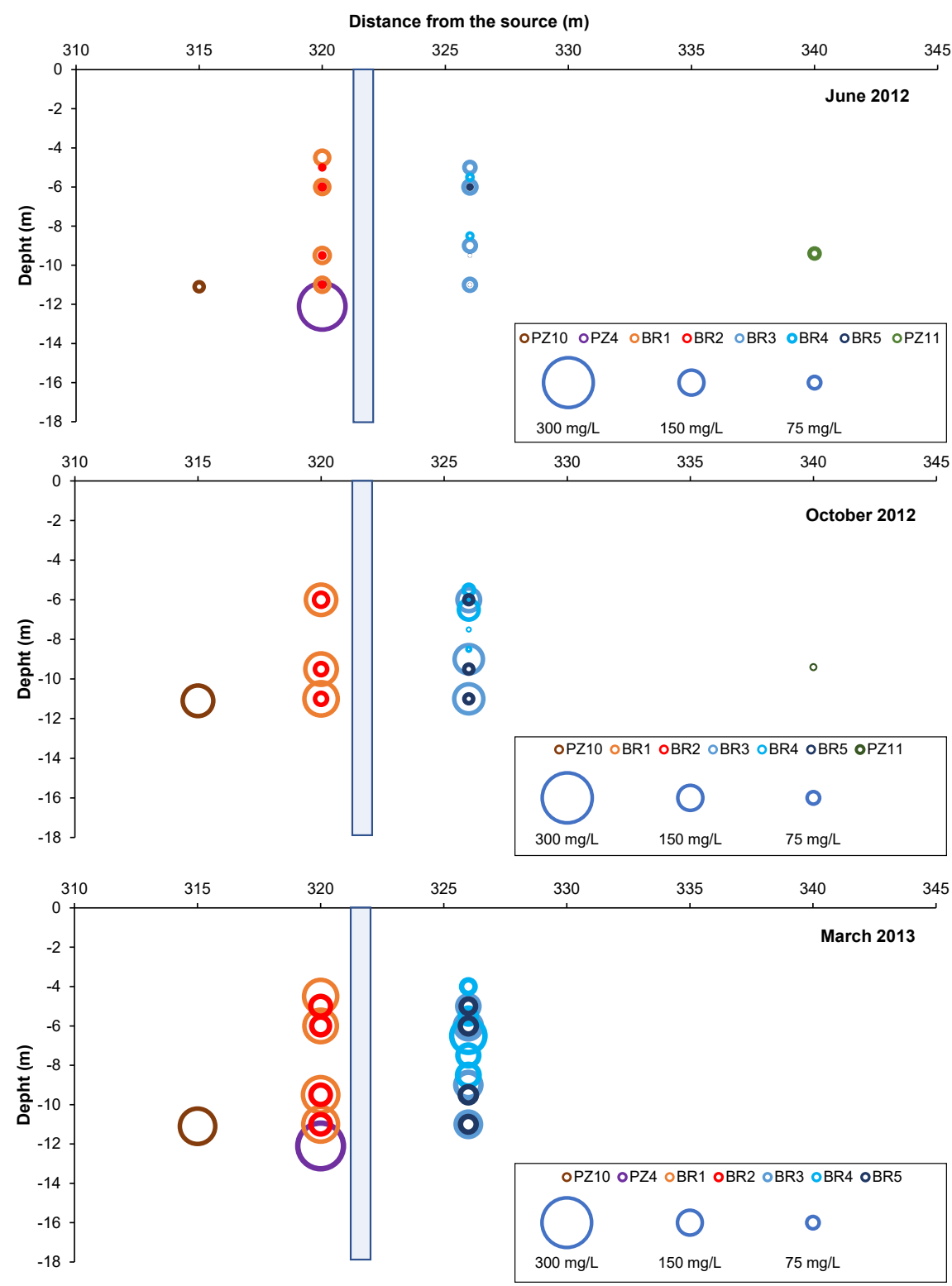




\section{Figure 6}

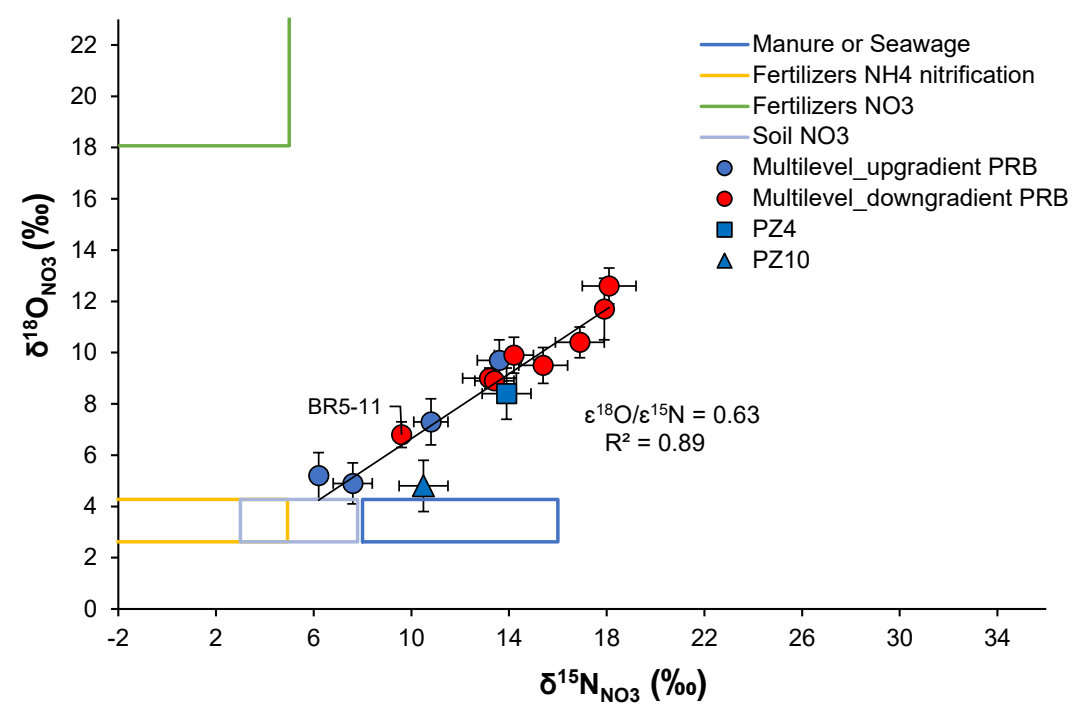




\section{Figure 7}

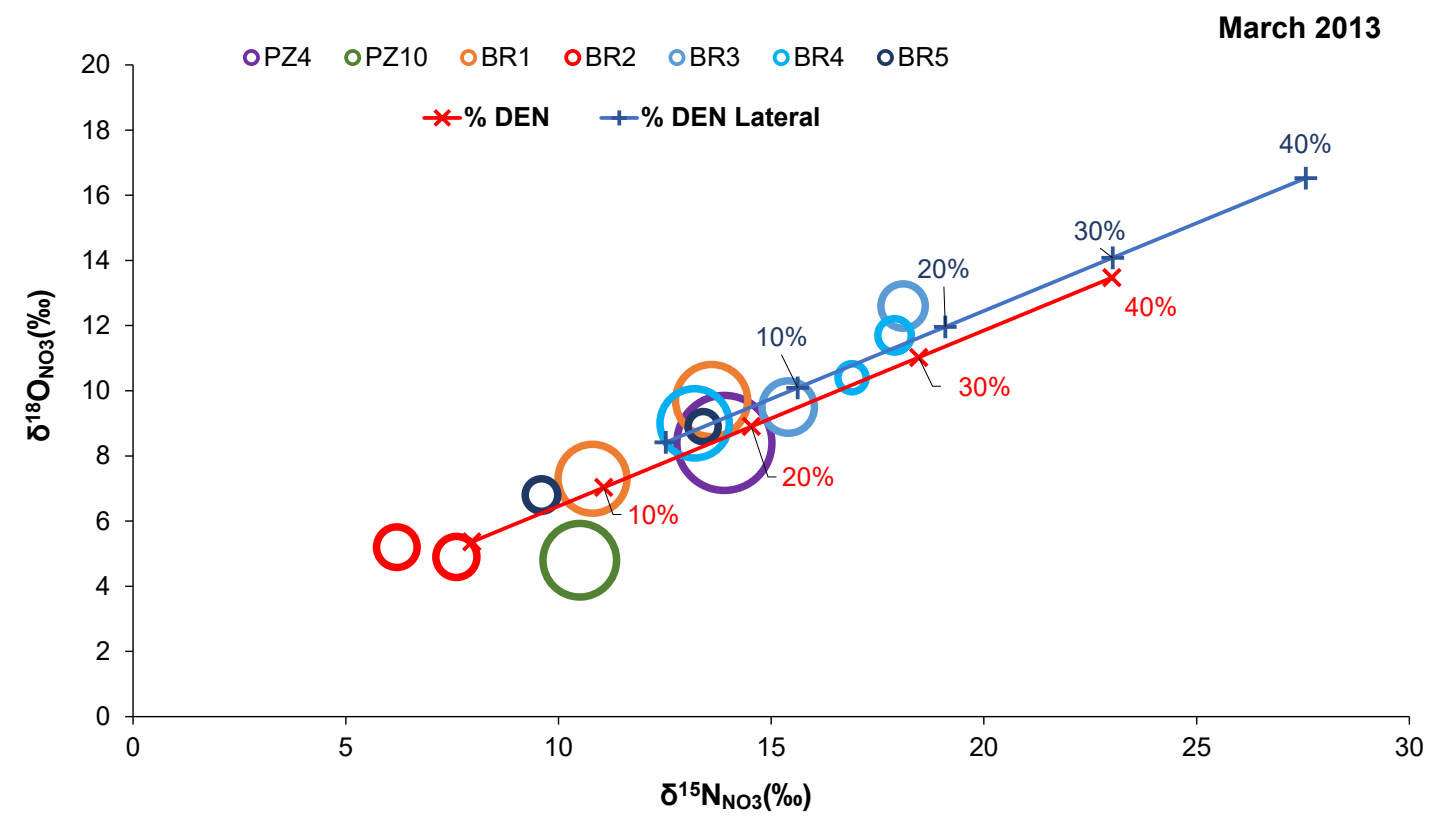


Table 1. Obtained $N$ and $O$ isotope fractionation values $\left(\varepsilon^{15} N\right.$ and $\left.\varepsilon^{18} O\right)$ and isotope ratios $\left(\varepsilon^{18} \mathrm{O} / \varepsilon^{15} \mathrm{~N}\right)$ for the laboratory experiments

\begin{tabular}{lccc} 
& $\boldsymbol{\varepsilon}^{15} \mathbf{N} \pm 95 \% \mathrm{Cl}$ & $\boldsymbol{\varepsilon}^{18} \mathrm{O} \pm 95 \% \mathrm{Cl}$ & $\begin{array}{c}\boldsymbol{\varepsilon}^{18} \mathrm{O} / \boldsymbol{\varepsilon}^{15} \mathbf{N} \pm \\
\mathbf{9 5 \%} \mathbf{C l}\end{array}$ \\
\hline $\mathrm{pH4}$ & $-36.1 \pm 7.1$ & $-16.1 \pm 3.1$ & $0.43 \pm 0.05$ \\
$\mathbf{M Q}$ & $-37.7 \pm 7.2$ & $-17.2 \pm 4.2$ & $0.45 \pm 0.02$ \\
\hline combined $\mathrm{pH4} \& \mathrm{MQ}$ & $-36.6 \pm 4.2$ & $-16.4 \pm 1.9$ & $0.43 \pm 0.02$ \\
\hline PRB & $-29.5 \pm 2.7$ & $-16.4 \pm 1.0$ & $0.54 \pm 0.07$ \\
\hline denitrification in the PRB experiment* & -20.5 & -15.5 & 0.76 \\
\hline
\end{tabular}

*Estimated using Eq. 9, assuming that in the PRB experiment two competing pathways occurred: ZVI-driven nitrate reduction (i.e. combined $\mathrm{pH} 4 \& \mathrm{MQ}$ ) and denitrification.

See the text for detailed information 